\title{
A determinação da idade das rochas
}

\author{
Celso Dal Ré Carneiro \\ Departamento de Geociências Aplicadas ao Ensino \\ Instituto de Geociências - UNICAMP \\ cedrec@ige.unicamp.br
}

Ana Maria Pimentel Mizusaki

Departamento de Paleontologia e Estratigrafia

Instituto de Geociências - Univ. Federal do Rio Grande do Sul

ana.mizusaki@ufrgs.br

Fernando Flávio Marques de Almeida

Escola Politécnica (aposentado) - Universidade de São Paulo

ffma@uol.com.br

\footnotetext{
* Este documento deve ser referido como segue: Carneiro, C.D.R.; Mizusaki, A.M.P.; Almeida, F.F.M. de. 2005. A determinação da idade das rochas. Terræ Didatica, 1(1):6-35. $<$ http:// www.ige.unicamp.br/ terraedidatica/>
}

\begin{abstract}
RESUMO Em pouco mais de 200 anos, a idade da Terra admitida pela ciência passou de alguns milhares para cerca de 4,56 bilhões de anos. Muitas analogias são empregadas para facilitar a compreensão dos conceitos de "tempo profundo" ou "abismo do tempo" mas, não obstante, essas idéias permanecem de difícil assimilação, pois as escalas e relações envolvidas são incomuns e freqüentemente complexas. A profunda inflexão no pensamento, e até mesmo na perspectiva humana, sobre a idade da Terra, decorre do amadurecimento da Geologia como ciência. Métodos específicos são necessários para determinação de idades de rochas e sua aplicação mais direta: o estudo do tempo geológico. Os métodos estratigráficos, paleontológicos e geocronológicos são empregados muitas vezes de forma integrada, para garantir resultados confiáveis; constituem parte essencial do conceito moderno de Geociências ou de Ciências da Terra. É conveniente fazer um estudo dos princípios teóricos e das principais - e acaloradas - polêmicas envolvidas, para se compreender de que modo o conhecimento acumulado a partir desses princípios e métodos "tornou" o planeta tão antigo; são idéias que afetaram profundamente a visão atual sobre a duração e permanência da espécie humana na Terra.
\end{abstract}

\begin{abstract}
Within the last two centuries there was a complete change on the concealed age of the Earth by specialists: it changed from some thousands to nearly 4,6 billion years. The study of geological time requires an integrated application of specific methods for the determination of rock ages: the stratigraphical, paleontological and geochronological methods. In order to get best results under different situations, the methods are often combined; this interdependence belongs to the foundations of the study of Earth's past. Analogies are often applied to help explaining the ideas of "deep time" or "abyss of time", but these are probably among the most complex concepts to be understood by people in general, for the complex relationships to be stablished and the unusual scales involved. The evolution of Geology as a science followed such inflexion on the way of thinking on the age of the Earth. Within the modern concept of both Geosciences or Earth Sciences, a knowledge on the heated discussions linked to the subject is needed to understand the way the principles and methods turned out the planet "aged".
\end{abstract}


"O número de anos em que nós, seres humanos, temos observado o nascer do Sol não é nada, virtualmente nada, na história de nosso planeta."

WEINER, Jonathan. 1988. p. 14.

\section{Introdução}

Hoje aceita-se com naturalidade que a Terra tenha cerca de 4,6 bilhões de anos (ver "How old is it?" National Geographic. set. 2001, Carneiro \& Almeida 1989, Mizusaki et al. 2000). Com certa facilidade, a história da natureza é dividida em períodos com dezenas de milhões de anos cada um (Gradstein et al. 2004); assim procedendo, podemos estender ao passado, cada vez mais, a origem da vida e do homem. Damos pouca atenção, entretanto, ao significado histórico e cultural dessas informações e, muitas vezes, menosprezamos que boa parte da humanidade desconheça ou refute essas idéias, tidas como inacreditáveis. De fato, dependemos de metáforas, na maior parte das vezes, para transmitir o significado e tentar compreender - por aproximação - a idéia de "tempo profundo" (Gould 1987).

\section{a. Escalas relativas e absolutas}

Estamos acostumados a medir o tempo nas nossas atividades diárias; dizemos que uma pessoa é pontual quando cumpre seus compromissos com certa precisão, ou seja, respeita uma escala de tempo medida em dias, horas, minutos e segundos. Neste exemplo de escala absoluta de tempo, todos os demais acontecimentos podem ser mais ou menos "amarrados". Mudar as convenções de tempo é aparentemente simples, mas exige planejamento: a definição dos "horários de verão", por exemplo, deve ser meticulosamente organizada, pois afeta uma infinidade de atividades humanas que acontecem ao mesmo tempo. Existem ainda as escalas relativas, que permitem seqüenciar os acontecimentos em uma dada ordem, admitida como a mais "lógica". Isso também obedece a certos procedimentos muito bem definidos. Quando afirmamos, por exemplo, que a maior parte das bacias petrolíferas brasileiras hoje conhecidas formou-se depois da separação dos continentes, não estamos dizendo "quando", mas apenas "em que ordem" um fenômeno veio depois do outro.

A medida do tempo requer, além de diferentes escalas, diversos graus de precisão. Se, para o astrônomo, por exemplo, a ordem de grandeza das relações de idade varia entre milhões e bilhões de anos, para o biólogo, que trata de eventos na vida de seres vivos, os intervalos relativos podem ser muito menores, da ordem de anos, meses ou dias. Físicos nucleares estudam processos e reações que ocorrem em intervalos pequenos, da ordem de $10^{-9}$ segundo. Em cada caso precisamos encontrar diferentes "relógios", cuja sensibilidade seja compatível com o evento que se pretende medir.

Um fenômeno geológico como a erosão afeta continuamente grandes porções da crosta terrestre, mas ao longo de uma vida humana é difícil notar mudança significativa no relevo de uma região. Depois de um episódio de chuvas, por exemplo, percebemos que as águas de um rio tornam-se avermelhadas, devido ao material argiloso que foi retirado de áreas altas próximas. Contudo, o processo é tão lento que milhares de anos são necessários para que sejam retirados poucos centímetros da camada superficial de um continente. Na moderna Geologia aplicam-se os dois tipos de escalas (absoluta e relativa), dentro das mais variadas ordens de grandeza, com a finalidade de reconstruir a história do planeta. Isso permite compreender o funcionamento da Terra nos dias de hoje e realizar previsões.

No estudo dos fenômenos do passado, o raciocínio indutivo e as analogias são essenciais, mas dependemos das "pistas" registradas nas rochas, analisadas por meio dos métodos geológicos de estudo do tempo: os estratigráficos, paleontológicos e geocronológicos.

\section{b. A polêmica sobre o tempo}

Na segunda metade do século XVIII, época em que James Hutton, considerado o "pai" da Geologia, começara a estudar rochas da região de Edimburgo, na Escócia, onde vivia, acreditava-se que a Terra teria sido formada por influência divina, há não mais que 7000 anos. Em 1654, o arcebispo irlandês James Ussher utilizara complexa combinação de dados para obter a idade da Terra. A partir da cronologia bíblica, dados históricos e estudos astronômicos, ele determinou a Criação do mundo e suas criaturas no sagrado ano 4004 AC, tendo John Lightfoot, diretor do St. Catherine's College, de Cambridge, Inglaterra, refinado ainda mais a datação do arcebispo, precisando que a Criação se deu exatamente às 9 horas da manhã do dia 26 de 
outubro daquele ano, data que foi impressa em várias edições da Bíblia. Por outro lado, no século XVIII, o pensador francês Buffon ${ }^{1}$ impressionouse com suas próprias conclusões: os eventos ocorridos no planeta sugeriam eras de dezenas de milhares de anos, ao que denominou de abismo do tempo. A idade da Terra estender-se-ia, segundo ele, por cerca de 75 mil anos (Gohau 1991).

Para explicar as repentinas extinções em massas de seres vivos, admitia-se que eventos catastróficos teriam ocorrido no passado da Terra. A teoria levou o nome de catastrofismo, sendo impregnada de dogmas religiosos. Sua refutação deve-se, entre outros, ao consistente trabalho de Sir Charles Lyell (1795-1875), para quem o relevo terrestre seria explicável pela atuação de forças contínuas, mas culminou na obra-prima de Charles Darwin "A origem das espécies", que desprezara tanto o catastrofismo, como os inúmeros atos espontâneos de criação de seres vivos. Darwin baseava-se em variadas - e numerosas - observações, deixando clara a influência de Lyell. Se o passado pode ser explicado pelos mecanismos que hoje atuam, necessariamente um longo tempo deveria estar envolvido na evolução. O mecanismo da seleção natural que fornecera enfrentou a dificuldade de ser dualista, ao tratar da evolução e da seleção em si mesmas. $\mathrm{Na}$ seleção natural não há um selecionador ativo; o processo se faz a posteriori e a natureza é que faz a seleção. Se não contasse com explicações de como a evolução ocorre, contudo, a teoria seria mera especulação e as idéias criacionistas seriam, ao menos, tão boas quanto elas.

Em meados do século XIX já haviam sido feitas inúmeras estimativas sobre a idade da Terra, utilizando-se vários modelos. Alguns métodos eram demasiadamente precários, como as medições baseadas em sedimentos: se fôssem medidos o volume dos sedimentos existentes e as taxas de erosão ou de sedimentação responsáveis por eles, poderia ser calculada a idade do sedimento mais antigo. Uma alternativa seria a medição de estratos sedimentares: assumindo-se que rochas com bandamento rítmico tivessem se formado por alternância de condições climáticas (verão e inverno, por exemplo), bastaria contar o número de estratos em um local com padrão repetitivo, para saber o número de anos envolvidos na deposição. As duas alternativas eram frágeis, porque jamais as taxas de erosão (ou de sedimentação) podem ser consideradas constantes: períodos de erosão rápida, na história geológica, podem se alternar com longos intervalos de erosão lenta. O método da contagem é, além disso, aplicável a intervalos muito pequenos de tempo. Na Suécia, por exemplo, a contagem de camadas alternadas sucessivas de uma rocha chamada varvito, de origem glacial, permitiu calcular que o gelo recuou do sul daquele país há 13.500 anos, tendo deixado o norte da Suécia há 8.700 anos (Bradshaw 1973).

\section{A determinação da idade da Terra}

William Thompson (1824-1907), homenageado com o título de Lorde Kelvin, admitira que a Terra viria sofrendo resfriamento contínuo desde um estado quente e fluido. Utilizara a idéia de Joseph Fourier sobre condução do calor; este determinara, ponto-a-ponto, em um sólido, em qualquer instante, tanto a temperatura, como a taxa de variação desta. Sadi Carnot, estudando a máquina a vapor, demonstrara que calor e trabalho poderiam ser convertidos um no outro. Thompson considerou, ainda, que uma parte do calor não está disponível para gerar trabalho nessas máquinas. $\mathrm{Da}$ mesma forma que na máquina a vapor, a fuga de energia térmica da Terra é irrecuperável e constante, como se observa em minas e poços profundos: quanto mais fundo se escava, maior a temperatura; o calor fluiria do interior para fora do planeta. Faltava, porém, a demonstração (um cálculo) de que a energia dissipada pudesse causar esgotamento dos sistemas naturais.

Partindo da suposição de que a Terra fazia parte do Sol e originalmente tinha a mesma temperatura que este, seria viável calcular a idade da Terra com alguma exatidão. Em 1846 ele comunicou os resultados, mesmo reconhecendo pontos fracos na abordagem: o tempo requerido para a Terra atingir as temperaturas do presente seria cerca de 100 milhões de anos, uma estimativa dentro de dois extremos: o tempo mínimo seria $20 \mathrm{Ma}^{2}$ e o máximo $400 \mathrm{Ma}$.

O limite de história da Terra em 100 Ma era estreito demais para que a seleção natural realizasse todo seu trabalho. Este obstáculo central à teoria da evolução, aliás, havia sido bem compreendido por Darwin: na 6a edição de "A origem das espécies"

1 Filósofo da época das Luzes (Iluminismo)

2 Utilizam-se as siglas "Ma" (mega-age) para milhões de anos e "Ga" (giga-age) para bilhões de anos 
(1872, apud Hellman 1999), admite ser um dos problemas mais sérios do modelo:

"Só posso dizer, primeiramente, que não sabemos qual é a taxa, medida em anos, em que as espécies se modificam e, segundo, que muitos filósofos não estão dispostos a admitir que saibamos o suficiente sobre a constituição do universo para especular com segurança sobre sua duração passada."

Muitos cientistas aceitaram os cálculos de Thompson e ele passou a apoiar os "verdadeiros" geólogos: pretendia ajudá-los a "tornar" científicas suas teorias, afastando aspectos inexatos ou dependentes de hipóteses. A teoria de Darwin seria incompleta, sem provas que refutassem a geração espontânea: a vida só procederia da vida. Em campo oposto reuniram-se outros cientistas (como Thomas Henry Huxley) que defendiam que, mesmo existindo inúmeros indícios de geração espontânea, as condições físico-químicas do passado geológico não seriam mais reproduzidas no presente. Thompson explicara a origem da vida pelos meteoritos, que seriam portadores de sementes. Eles teriam encontrado condições favoráveis na Terra para iniciar a vida.

Os rumos do debate mudaram graças a três descobertas inesperadas para os cientistas da época: a descoberta do elemento rádio por Madame Curie, a descoberta, pelo marido de Mme. Curie, de que o rádio irradia constantemente calor e a terceira, por Lord Rayleigh, de que "o rádio está largamente distribuído através de todas as rochas" (Holmes 1923, p. 19). Fôra descoberta uma imensa fonte de calor: a radioatividade; isso revelou, no início do século XX, que geólogos e biólogos estavam corretos. Um discípulo de Kelvin, Ernest Rutherford, foi decisivo no avanço dos cálculos sobre a idade da Terra.

\section{a. A idade da crosta terrestre}

Com o advento da geocronologia e os progressos no conhecimento do Sistema Solar tornou-se possível conhecer com precisão a idade da Terra. O Sistema Solar, que inclui o Sol e sua corte de planetas, asteróides e cometas que o orbitam, formou-se a partir de acreções de gases e poeiras contidos na nuvem solar. Os meteoritos são objetos provenientes do Sistema Solar que caem na superfície da Terra. São de vários tipos, entre eles os chamados condritos, que possuem inclusões cristalinas esféricas, os condros, formadas a partir de gotículas silicatadas. Os condros são reunidos por inclusões refratárias ricas em $\mathrm{Ca}, \mathrm{Al}$ e $\mathrm{Ti}$, contidos numa matriz. Os condritos são amostras do material que serviu à formação do Sol e seus planetas e asteróides. Suas inclusões refratárias constituem os mais velhos objetos do Sistema Solar. Datações pelo Método urânio-chumbo permitiram conhecer com precisão a idade dessas inclusões refratárias: $4.566 \pm 3$ $\mathrm{Ma}$ (Zanda 1996). Admite-se que a Terra como um corpo fundido formou-se durante os $120 \mathrm{Ma}$ seguintes. Desconhece-se a idade de consolidação de sua crosta, mas datações recentes de rochas da Austrália e norte do Canadá indicam que já estava formada há uns 3.900 Ma. Assim, permanece indefinida a idade do início do Arqueano.

Admite-se que logo após a consolidação da crosta, quando já se realizavam processos em sua superfície ligados à presença de água, surgiu a vida. Sinais dela acham-se presentes na natureza de cristais de apatita contidos em rochas metassedimentares datadas recentemente em 3,85 Ga, em ilha da costa noroeste de Groenlândia (Stephen Moyzsis, cit. in Svitl 1998). Surgiu provavelmente como resultado de fenômenos químicos, pelo que também poderá existir em outros planetas de características comparáveis às da Terra.

\section{b. Os principais métodos geológicos de estudo do tempo}

\section{“(...) um mundo sem vestígio de um início nem perspectiva de um fim". \\ James Hutton}

Antes de chegar aos sofisticados métodos de datação de rochas e estudo da idade da Terra, convém lembrar que uma das pedras fundamentais erigidas por Hutton para entender as dimensões do tempo geológico foi o reconhecimento de princípios $^{3}$ das investigações para se determinar idades de rochas e das seqüências das quais elas fazem parte. Os principais métodos de estudo da moderna Geologia, abordados a seguir, são os estratigráficos, os paleontológicos e, finalmente, os geocronológicos. Assim, começaremos o estudo pelos métodos estratigráficos.

3 Princípio consiste em um ponto de partida; é uma referência, de certo modo inquestionável, sem a qual não se pode avançar, em Ciência, com qualquer segurança. 


\section{Métodos estratigráficos}

Uma atividade freqüente do geólogo é dividir os tipos de rocha de uma dada região - ígneas, metamórficas ou sedimentares - segundo diferentes unidades, que devem ser discretas, reconhecíveis pelos atributos particulares e, ao mesmo tempo, suficientemente espessas e extensas para serem representadas em um mapa geológico. As unidades mapeáveis são denominadas formações e distinguemse entre si por meio da composição, cor, textura, idade relativa e outras propriedades.

Para realizar esse estudo, é preciso aplicar alguns princípios da Estratigrafia - a ciência que estuda os estratos sedimentares, incluindo minerais e fósseis presentes, sua ordenação cronológica, distribuição geográfica e ambientes de sedimentação (Rohn 2000).

Os princípios permitem ordenar as rochas estratificadas no tempo, a partir do estudo de suas relações laterais e verticais em uma dada área (Eicher \& McAlester 1980). Três deles foram estabelecidos ainda em 1669 por Nicolas Steno, no estudo da geologia do oeste da Itália: o princípio da horizontalidade original, a lei da superposição e o princípio da continuidade lateral original. O quarto princípio foi definido em 1795 por James Hutton, geólogo que pela primeira vez diagnosticou na Escócia a importância do estudo dos vários tipos de contatos entre as unidades de rochas. Trata-se do princípio das relações de intersecção. Para facilitar, tomemos o enunciado original de cada um, analisando-se em separado a importância, limitações envolvidas e relações implícitas no conceito.

\section{a. Lei da superposição}

Em uma seqüência de estratos indeformados, cada camada é mais jovem que aquelas abaixo dela e mais antiga do que aquelas situadas acima.

Embora alguns autores refiram-se a essa formulação como um princípio, a idéia de superposição ganhou "status" de lei. Leis científicas constituem afirmações rigorosas sobre a maneira regular pela qual um fenômeno natural ocorre, sob dadas condições. A lei foi reconhecida pelo pioneiro Nicolas Steno ("não antes de 1669", como indicado por Tarbuck \& Lutgens 1996); aplica-se a camadas de origem sedimentar e até mesmo a derrames de lava e camadas de cinza provenientes de erupções vulcânicas. Uma redação equivalente poderia ser: "dadas duas camadas, a que estivesse originalmente abaixo de outra é a mais antiga". Esta é, segundo Read \& Watson (1968) a reafirmação da "primeira lei [da superposição]" postulada por William Smith (1769-1839). Tal como o exemplo de uma parede de tijolos, os andares de um edifício ou as camadas de um bolo, a idade de uma seqüência de multicamadas pode ser estabelecida considerando-se que a camada basal é a mais antiga, pois formou-se primeiro; a última, evidentemente, é a mais jovem.

Embora simples, este conceito é de todos o mais importante, pois a história geológica de uma região qualquer é interpretada de acordo com a ordem de deposição (ver Press \& Siever 1986, p. 28 30) das sucessões ou seqüiências sedimentares (Fig. 1). Muitas vezes, porém, não é simples determinar qual a posição de topo de uma camada, ou seja, não se sabe se ela está em posição normal ou invertida. Neste caso, recorre-se ao estudo das estruturas sedimentares, ou seja, feições que possam esclarecer a posição do estrato durante a deposição. Algumas estruturas sedimentares são ambígüas, ou seja, não indicam topo e base e, portanto, são inúteis para essa tarefa.

Uma seqüência deposicional é formada por estratos concordantes, relacionados entre si pela origem comum e delimitados, na base e no topo, por discordâncias ou descontinuidades na sucessão sedimentar. As discordâncias representam hiatos temporais expressivos durante os quais não houve deposição de camadas ou, se ocorreu sedimentação durante certo intervalo de tempo, esse registro foi perdido devido à erosão (hiatos deposicionais ou erosionais). O termo descontinuidade pertence a uma ordem de grandeza menor do que discordância (Popp 1987).

O registro sedimentar é formado por "episódios" de sedimentação, alternados com períodos de não-deposição; a sucessão desses fenômenos é

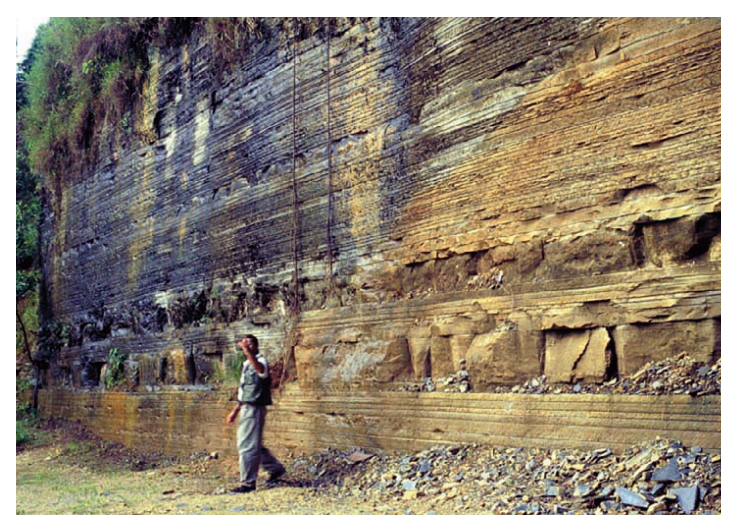

Figura 1 - Camadas sedimentares horizontais do Grupo Itararé na região de Itu (SP) 


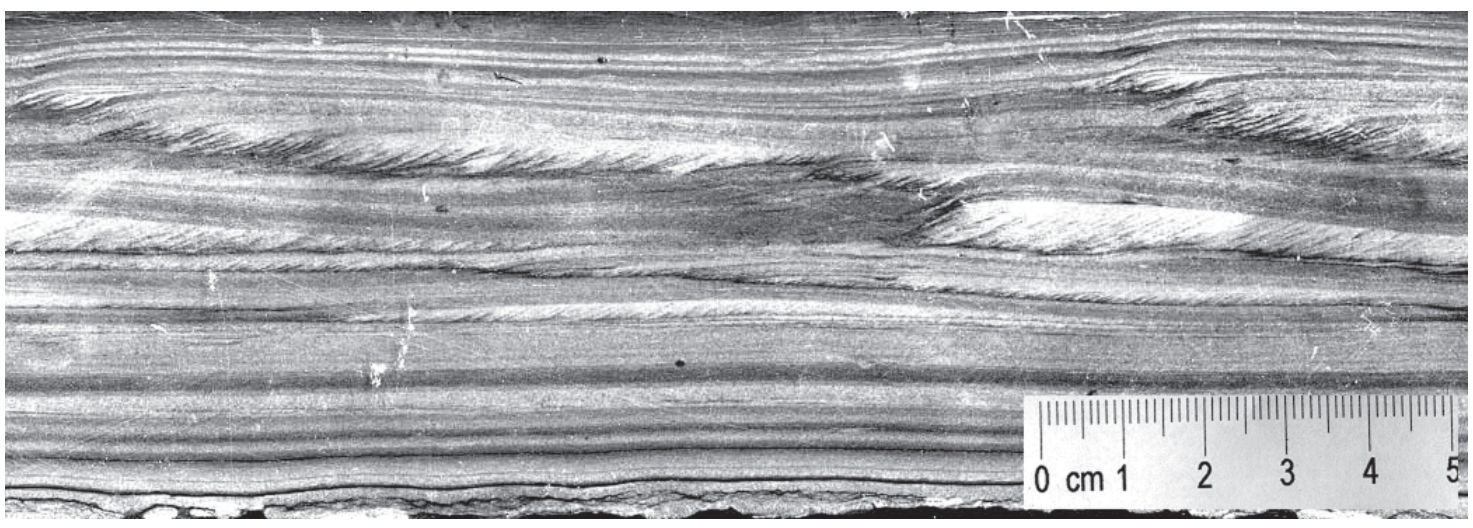

Figura 2 - Estratificação sedimentar em turbiditos de sedimentos do Grupo Itararé, contendo finas camadas e discretas descontinuidades, que formam planos horizontais ou inclinados. As estruturas são indicativas de topo e base; mesmo local da foto anterior, Itu (SP)

registrado pelas camadas de sedimentos que constituem a estratificação (Fig. 2). A natureza episódica do registro sedimentar consiste, basicamente, em uma sucessão finita de camadas separadas por descontinuidades, cuja duração no tempo é pequena quando comparada ao tempo envolvido na formação de uma discordância, por exemplo.

\section{b. Princípio da horizontalidade original}

As formações sedimentares são depositadas originalmente na posição horizontal. Qualquer mergulho que elas apresentem é resultado de subseqüente dobramento ou basculamento.

A acumulação de sedimentos ocorre na maioria das vezes em uma disposição planar ou muito próxima da horizontalidade. Assim, este princípio constitui a base de qualquer interpretação regional em ambientes de rochas estratificadas. Mesmo que algumas estruturas encontradas em camadas sedimentares sejam desde o início dispostas em camadas inclinadas, como as marcas de onda em areias de praia, algumas frentes de deposição de areia em dunas ou barras de rio, seus limites mais gerais são dados por superfícies que se mantiveram horizontais durante a sedimentação.

Há exceções, no entanto, como inúmeras lâminas sedimentares (ver Fig. 2), alguns depósitos inclinados em encostas montanhosas, camadas depositadas nos flancos de grandes dunas (ver Almeida \& Carneiro 1998) e certos depósitos marinhos, como em bordas de grandes recifes submarinos. Nesses casos, a inclinação original da camada não deve ser assumida como zero ou próxima de zero, mas interpretada com algum cuidado.

\section{c. Princípio da continuidade lateral original}

Seqüências estratigráficas idênticas expostas em lados opostos de um vale devem ser interpretadas como restos de camadas que já foram contínuas na área na qual o vale foi aberto.

Steno reconhecera que muitas formações atualmente interrompidas por vales ou cadeias de montanhas eram contínuas, antes que as feições mais jovens se implantassem. Uma camada sedimentar forma-se, na época de sua deposição, como uma lâmina contínua que terminaria apenas ao se afinar até o desaparecimento, ou pela mudança gradual para uma camada de composição diferente ou ainda pelo encontro de uma parede ou barreira, como a linha de costa, que confinasse a área deposicional (Press \& Siever 1986, p. 28).

Embora aparentemente simples, o raciocínio envolve notável discernimento, mesmo admitindo-se que a maioria das formações geológicas é extensa e espalha-se em todas as direções ao longo de grandes áreas da crosta terrestre. Os limites destas podem ser bruscos ou graduais, dependendo de suas relações com as unidades dispostas ao lado, acima ou abaixo. Tais relações foram construídas quando a bacia sedimentar em que as camadas se depositaram esteve em processo de subsidência ${ }^{4}$, durante intervalos de tempo incalculáveis, há muito tempo atrás. O princípio traz implícito que a dinâmica da natureza pode alternar, na mesma parte da crosta terrestre, condições de subsidência (quando os sedimentos são depositados e aprisionados) com condições de soerguimento, quando rochas

4 Subsidência é o fenômeno de afundamento gradual de uma parte da crosta terrestre 


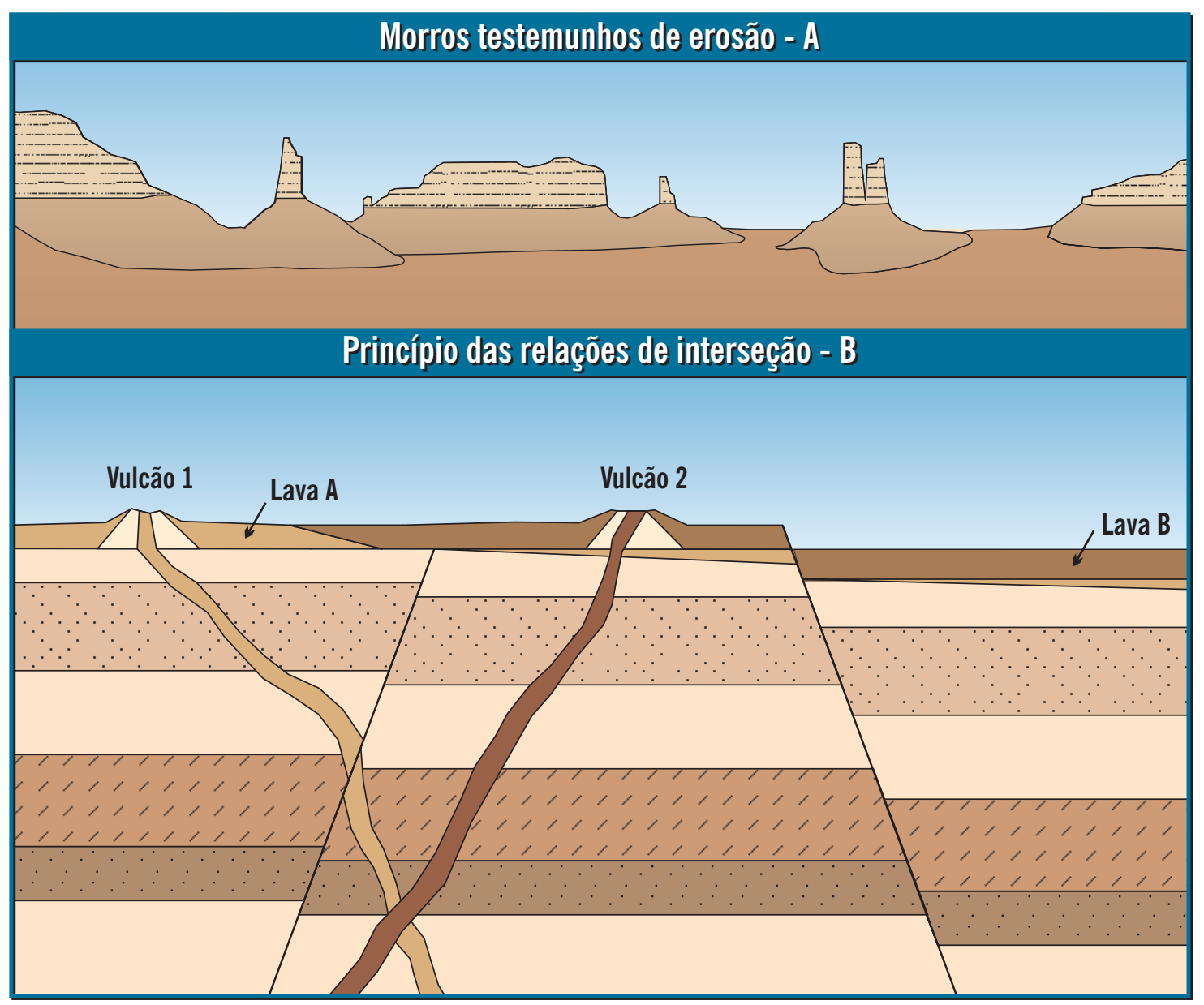

Figura 3 (a e b) - Aplicação prática dos Princípios da Estratigrafia: a) Princípios da Continuidade Lateral e da Superposição: testemunhos de erosão da paisagem rochosa do deserto do Arizona. As camadas foram depositadas em estágios sucessivos, da base para o topo, umas sobre as outras; b) Princípios da Superposição e das Relações de Intersecção: uma seqüência de camadas sofreu a intrusão de magma que levou à formação do conduto que originou o vulcão 1 e a lava $A$. 0 conduto foi posteriormente cortado por uma falha inversa. Mais tarde, novo conduto corta o anterior, tendo originado o vulcão 2 e a lava B. Uma falha normal é a última estrutura observada, pois corta as demais.

anteriormente formadas são erodidas e podem desaparecer, ou ficarem representadas somente pelos chamados "testemunhos" (Fig. 3a).

\section{d. Princípio das relações de intersecção}

Qualquer rocha que foi cortada por um corpo intrusivo ígneo ou por uma falha é mais antiga que o corpo ígneo ou falha.

As relações de intersecção, de certo modo, fazem parte do senso comum. Em diferentes situações

5 Testemunhos são restos de camadas ou massas de rocha, isolados geograficamente na paisagem. reconhece-se a idéia de cronologia; em outras, ela permanece implícita, mas não necessariamente as pessoas percebem com clareza o(s) mecanismo(s) envolvido(s) no fenômeno considerado.

Observando-se, por exemplo, uma casa sendo construída, vemos que há uma sucessão de etapas, desde a definição dos limites do lote, a terraplenagem, as fundações, as paredes, o telhado, a pintura e assim por diante. Em uma sucessão de camadas cortadas por falhas ou por um veio, por exemplo, a ordem de aparecimento das estruturas pode ser determinada se reconhecermos qual feição corta outra. A mais jovem delas será a que atravessa todas as demais (Fig. 3b). 


\section{Métodos paleontológicos}

O estabelecimento da ordem de sucessão das camadas fossilíferas da Grã-Bretanha foi sobretudo obtido pelos trabalhos de William Smith (17691839), que foi levado a concluir que cada camada continha fósseis peculiares e que estes se sucediam na mesma ordem, pelo que formações muito afastadas de outras podiam ser consideradas como praticamente contemporâneas desde que contivessem grupos semelhantes de fósseis - os chamados fósseis-índices. De tal modo, foi pioneiro no reconhecimento dos fósseis para determinar a idade relativa das rochas estratificadas.

\section{a. Lei da Sucessão Biológica}

O estabelecimento de uma coluna padrão do tempo geológico à qual possam ser correlacionadas as camadas fossilíferas baseia-se na Lei da Sucessão Biológica, que pode ser assim enunciada:

Os organismos sucederam-se no tempo, dos mais simples aos mais complexos, e uma determinada espécie ou grupo de organismos, após sobreviver durante tempo mais ou menos prolongado, desapareceu do planeta para não mais ressurgir.

Para exemplificá-la indicamos o caso do importante grupo de crustáceos denominados trilobitas, que surgiram em princípios do tempo chamado Paleozóico e desapareceram no seu final.

Tanto mais precisa será a correlação das camadas quanto mais curto o tempo em que viveram seus organismos e maior a dispersão geográfica que apresentaram no planeta. Nesse sentido, são particularmente importantes para correlações os animais marinhos, como as espécies de trilobitas, graptólitos, amonitas, foraminíferos etc. Podem existir dificuldades em se saber com exatidão o momento e local em que determinada espécie ou grupo de organismos surgiu, para mais tarde se extinguir no planeta, devido ao diacronismo que esses fatos apresentam em bacias diferentes. Entretanto, os progressos da paleontologia permitiram estabelecer a escala da evolução da vida e verificar que sua história não foi uniforme mas existiram momentos geológicos em que alta porcentagem de seres então viventes foram extintos. Houve outras ocasiões, durante as quais determinados grupos surgiram rapidamente, ou tiveram seu desenvolvimento explosivamente incrementado.

Diversos fatores, nem todos ainda bem conhecidos, responderam por essas irregularidades, tais como variações de clima, relevo, composição da atmosfera (sobretudo aumento do oxigênio, vapor de água e bióxido de carbono), transgressões e regressões marinhas devidas a glaciações ou causas tectônicas, modificações da temperatura e salinidade do mar, vulcanismo, extensão dos continentes e oceanos, impacto de corpos celestes etc. Entre as causas de ordem astronômica incluem-se o esporádico aumento de radiação solar emitindo raios$\mathrm{X}$, raios ultravioleta e partículas tais como prótons; radiações provenientes da explosão de supernovas da Via Láctea e ainda a passagem periódica do Sistema Solar por certas zonas da galáxia, o que poderia explicar a ciclicidade das extinções reconhecida por alguns pesquisadores, citados por Albritton Jr. (1989). Embora não haja consenso entre os cientistas sobre as causas dessas descontinuidades, as ocasiões de evolução explosiva de grupos de organismos e as de sua extinção em massa existem e, juntamente com o surgimento de grupos de animais e vegetais, assinalam momentos importantes na evolução da vida. Essas descontinuidades permitem estabelecer divisões na escala do tempo geológico.

\section{b. Escala do tempo geológico}

A escala do tempo geológico foi estabelecida com base na sucessão biológica (Quadro 1). Os nomes das maiores divisões, chamadas Eons, referemse ao caráter geral da vida em cada uma. Com a introdução das datações pelos métodos geocronológicos foi possível estabelecer limites numéricos entre elas (Fig. 4).

O Eon mais antigo chamou-se Arqueozóico (do grego, vida antiga) e modernamente Arqueano, compreendendo o intervalo de tempo entre 2.500 Ma e pelo menos $3.900 \mathrm{Ma}$, quando se sabe que já existia uma crosta na Terra. O Eon seguinte, denominado Proterozóico (do grego, vida primitiva) corresponde ao tempo entre 2.500 e $570 \mathrm{Ma}$. Segue-se a ele o Eon Fanerozóico (vida visível).

As rochas arqueanas são geralmente muito deformadas e metamorfizadas, sendo destituídas de fósseis de valor cronológico. Indícios de vida no planeta, representados por compostos orgânicos e raros microfósseis globulares, filamentosos e bastonetes, possivelmente originados de bactérias, ocorrem em rochas datadas de até 3,85 Ga. O maior problema de identificação e estudo desses materiais é a falta de partes duras, existentes em organismos mais novos, que são mais fáceis de se preservar. Estromatólitos são estruturas concêntricas 
Quadro 1 - A História da Terra, de acordo com o registro fossilífero

\section{A História da Terra contada pelos fósseis}

Os dados paleontológicos separam a história da Terra em eon Arqueano, que começa com a solidificação da crosta, há mais de 3 bilhões e 900 milhões de anos e termina há 2 bilhões e 500 milhões de anos. O eon seguinte, o Proterozóico, vai de $2,5 \mathrm{Ga}$ a $570 \mathrm{Ma}$. Os fósseis que registram a existência da vida no planeta mostram que ela evoluiu pouco durante os primeiros bilhões de anos, por muito tempo as formas de vida não passaram de seres unicelulares. Veja os principais períodos dessa história:

- Pré-Cambriano - Os registros fósseis indicam o aparecimento de formas pluricelulares somente há cerca de $700 \mathrm{Ma}$, no final do período Proterozóico: no sul da Austrália, em um local chamado Ediacara, foram encontrados registros de uma fauna de animais multicelulares marinhos, que, depois, foram descobertos também em outras regiões. Eram organismos moles, que parecem ter sofrido extinção em massa ainda antes do final do Proterozóico.

- Cambriano - Há $570 \mathrm{Ma}$, ocorreu a "explosão cambriana”, assim chamada porque os registros fósseis indicam que houve uma grande diversificação das formas vivas. Além de animais de corpo mole, surgiram, na vida marinha, novos seres com o corpo protegido por carapaças duras, alguns com pernas e outros apêndices.

- Ordoviciano-Aparecem os primeiros vertebrados, ancestrais dos peixes atuais.

- Siluriano-Aparecem as primeiras plantas terrestres e, junto com elas, os primeiros artrópodes terrestres

- Devoniano - Os insetos voadores mais antigos conhecidos são desse período, assim como os verdadeiros peixes (com mandí- bulas). No Devoniano Superior, os anfíbios ocuparam a Terra.

- Carbonífero - Nesse período, predominaram grandes florestas, que deram origem às reservas de carvão mineral. Surgem os répteis.

- Permiano - Durante a era Paleozóica, aconteceram várias extinções em massa. A maior delas aconteceu no fim do Permiano, assinalando o limite entre as eras Paleozóica e Mesozóica. Calcula-se que cerca de $80 \%$ das espécies animais então existentes desapareceram em alguns milhões de anos.

- Triásico ${ }^{6}$ - Os vertebrados continuaram a evoluir, diferenciando-se em répteis e mamíferos.

- Jurássico - No Mesozóico, a Era dos Répteis, esses animais ganharam grande importância. Durante o Jurássico, surgiu a primeira ave, originada dos dinossauros. Surgiram também as primeiras plantas com flores.

- Cretáceo-O fim do Cretáceo é marcado por uma grande extinção, que fez desaparecer quase a metade das espécies viventes. Dos répteis só restaram crocodilos, lagartos, tartarugas e cobras, mas os dinossauros e outros répteis de grande porte, como os ictiossauros e os pterossauros, desapareceram. Discute-se o que causou essa extinção: a hipótese mais aceita é a queda de um meteoro (asteróide ou cometa) com cerca de $10 \mathrm{~km}$ de diâmetro.

- Terciário - Domínio dos mamíferos. Animais pequenos no princípio, eles se desenvolveram após a extinção dos grandes répteis. Evolução dos primatas e diversificação dos insetos e peixes.

- Quaternário-Os vertebrados evoluem rapidamente. Aparece o homem moderno. colunares, resultantes da acreção de detritos capturados e aglutinados por colônias de bactérias e algas cianofícias, existindo em rochas de até 3.600 $\mathrm{Ma}$, também atestando ser esse valor um mínimo para a existência da vida na Terra. Representam a mais antiga comunidade de vida conhecida. Proliferaram no Proterozóico, sendo sobretudo abun- dantes no fim desse Eon. Embora sejam às vezes úteis para correlações entre continentes, são fósseis de valor cronológico muito reduzido.

6 Almeida \& Carneiro (2004) adotam para a base do erátema Mesozóico o termo Triásico, que significa "triádico, composto por três, triplo", salientando que a palavra "Triássico", também usual, sofre óbvia influência de "Jurássico" e do Inglês Triassic. 
Os fósseis e indícios de compostos orgânicos correspondentes a cerca de três quartos da existência da vida no planeta mostram que ela então evoluiu muito lentamente, pelo que não fornece elementos para o estabelecimento de limites biológicos para divisões do chamado Pré-Cambriano, que reúne esses dois Eons. De tal modo as subdivisões do Pré-Cambriano são feitas com base em eventos tectônicos de maior grandeza, como o aparecimento de grandes blocos rígidos da crosta (crátons) e a evolução de faixas de dobramentos.

Apesar da lenta evolução da vida pré-cambriana, ela assistiu ao aparecimento dos organismos microscópicos unicelulares (protozoários) e, mais tarde, há uns $3 \mathrm{Ga}$, ao dos multicelulares (metazoários), que evoluíram para formas mais complexas, assim como ao advento da reprodução sexuada há uns $2 \mathrm{Ga}$. Há cerca de $700 \mathrm{Ma}$, portanto já próximo do final do Proterozóico, um acontecimento biológico importante ficou assinalado pelo aparecimento da primeira fauna de metazoários, animais multicelulares certamente marinhos, encontrados em Ediacara no sul da Austrália (Gaessner 1984) e também em outros continentes. Eram animais moles, aparentemente não vinculados a phyla fanerozóicos.

Tal fauna sofreu extinção em massa antes do término do Proterozóico, sucedendo-se, após algumas dezenas de milhões de anos, a "explosão cambriana" quando, a par de animais de corpo mole embora complexo, surgiram os primeiros metazoários providos de carapaças, pernas e outros apêndices duros, passíveis de fossilização. Uma evolução explosiva da vida animal, toda ela marinha, levou, nessa ocasião, ao aparecimento dos phyla de quase todos os metazoários modernos. Esse evento é um marco importante na escala do tempo geológico baseada na evolução da vida, assinalando o início do Eon Fanerozóico.

De acordo com a evolução da vida os Eons são divididos em Eras, estas em Períodos, que por sua vez se dividem em Épocas, que ainda admitem subdivisões menores determinadas por gêneros e espécies fósseis característicos e datações radiométricas. $\mathrm{Na}$ correspondência com a coluna estratigráfica os períodos equivalem aos sistemas e as épocas às séries. A figura 4 indica as divisões maiores da escala do tempo geológico, sua idade em anos e relações com as etapas maiores da evolução da vida.

Uma dúzia de extinções em massa da vida animal manifestou-se durante o Fanerozóico. A maior delas teve lugar no Permiano Superior a terminal, assinalando o limite entre as Eras Paleozóica e Mesozóica. Estima-se que entre 10 a 15 milhões de anos finais do período cerca de $83 \%$ dos gêneros de invertebrados marinhos desapareceram (Sepkoski Jr. 1986). Também se extinguiram mais de $80 \%$ das famílias de répteis, três quartas partes das de anfíbios (Olson 1982, Sepkoski Jr. 1982) e $30 \%$ dos insetos, mas a vida vegetal foi pouco perturbada. Nessa ocasião quase desapareceram os amonóides, crinóides e corais, muito se reduziram os peixes e extinguiram-se os trilobitas. A extinção permiana foi a primeira a afetar de modo significativo a vida terrestre, pois nas anteriores a maioria da vida era marinha. No Permiano os continentes haviam se reunido num supercontinente que se denominou Pangea (em português, adota-se Pangéia); vários autores consideram esse fator como a principal causa da grande extinção.

Outros quatro episódios expressivos de extinções se deram no Ordoviciano Superior quando 57\% dos gêneros marinhos desapareceram; no Devoniano Superior, com grande perda de famílias de invertebrados marinhos e de peixes; no Triásico Superior, com o desaparecimentos de répteis e anfíbios primitivos e de $75 \%$ das espécies de invertebrados marinhos. A última grande extinção se deu no Cretáceo terminal. Foi a segunda em grandeza, tendo-se realizado há 65,5 $\mathrm{Ma}$, no limite entre o Cretáceo e o Terciário (conhecido como limite KT). Causou o desaparecimento de $47 \%$ dos gêneros animais, incluindo os répteis voadores e marinhos e muitos dos terrestres, como os dinossauros. Extinguiram-se cerca de $15 \%$ das famílias de animais marinhos, inclusive as amonitas (Sepkoski Jr. 1982). Nos dez milhões de anos finais do Cretáceo pelo menos 30 gêneros de dinossauros habitavam o planeta, vários dos quais viveram até o limite $\mathrm{K}$ T, porém nenhum parece ter sobrevivido à grande extinção. Dos répteis só restaram crocodilos, lagartos, tartarugas e cobras.

Os primeiros vegetais terrestres são representados por esporos provenientes de plantas desconhecidas, datados do Ordoviciano Inferior. $\mathrm{Na}$ época mais nova do período Siluriano os escorpiões foram os primeiros animais a adotarem a respiração aérea. Os insetos voadores mais antigos surgiram no Devoniano. Os primeiros vertebrados, representados por peixes cobertos por couraças e sem maxilar (ostracodermos) são do período Ordoviciano. Os verdadeiros peixes, ainda com 
esqueleto interno pouco ou não ossificado, são do Devoniano Inferior. No Devoniano Superior os vertebrados ganharam a terra com o aparecimento dos anfíbios, que originaram os répteis no Carbonífero Superior. Nos tempos mais novos deste período desenvolveram-se as florestas de Cryptogamas Vasculares e Gymnospermas formadoras dos carvões que deram o nome ao sistema.

No Triásico Superior e início do Jurássico começou a se partir o supercontinente Pangéia, fragmentação que se acentuou no decorrer do Jurássico e Cretáceo. A grande extensão de plataformas continentais dela decorrente e as transgressões marinhas favoreceram a diversificação dos invertebrados

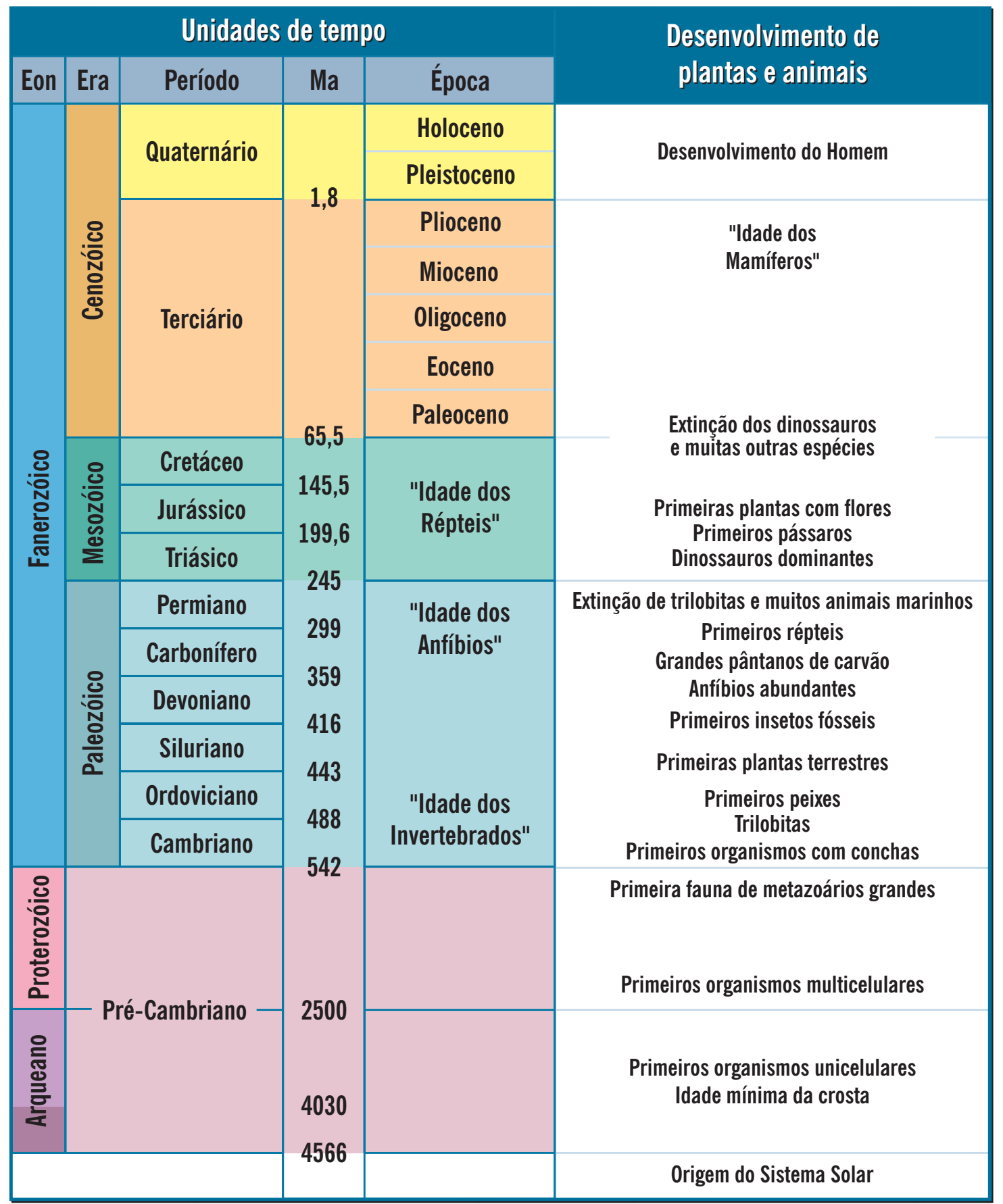

Figura 4 - Escala do Tempo Geológico, com indicação de alguns eventos importantes na evolução da vida (modif. de Tarbuck \& Lutgens 1996 e Gradstein et al. 2004) 
de águas rasas. Os vertebrados passaram a evoluir, diferenciando-se nos continentes separados. Os répteis tornaram-se importantes, com o aparecimento dos crocodilianos, dinossauros terrestres, plesiossauros e ictiossauros marinhos e pterossauros voadores. Surgiram os mamíferos no fim do Triásico, originados dos répteis, mas sua evolução foi lenta até o fim do Cretáceo. De acordo com recente identificação de penas no dorso de um pequeno réptil do Triásico Superior, Longisquama insignis, feita por paleontólogos americanos e russos, ele foi um ancestral das aves, que até agora tem-se considerado provirem dos répteis dinossauros.

Durante o Jurássico continuaram e evoluir as faunas vindas do período anterior, acrescidas de aves primitivas, como o célebre Archaeopteryx. Os répteis ganharam grande importância e juntamente com os do Cretáceo justificam reconhecer-se o Mesozóico como a Era dos Répteis. A vegetação, constituída sobretudo de coníferas e cicadáceas como no Triásico, viu surgirem as Angiospermas, as primeiras plantas com flores.

No Cretáceo a flora e a fauna vindas do período anterior continuaram sua evolução sem grandes transformações. Os répteis terrestres, marinhos e voadores atingiram seu apogeu. $\mathrm{Na}$ flora cretácea destaca-se o papel crescente das Angiospermas em relação às Gimnospermas. $\mathrm{O}$ mais antigo fóssil conhecido das Angiospermas pertence ao Hauteriviano e o Cenomaniano é abundante em fósseis desses vegetais.

Em 1760 o italiano Arduino, numa tentativa de dividir os estratos, propôs sua classificação em Primitivos, Primários, Secundários e Terciários. Os três primeiros termos caíram em desuso, mas permaneceu o Terciário, tendo Lyell denominado PósTerciários os estratos que incluíam os produtos da grande glaciação e restos humanos, que posteriormente viriam a fazer parte do período Quaternário.

As camadas correspondentes à Era Cenozóica (Fig. 4, Quadro 1) foram divididas primeiramente por Lyell em seus "Princípios de Geologia" (18301833), em três séries, com as designações de Eoceno (que significa aurora do recente) cujas camadas continham somente 3 a $4 \%$ das conchas modernas; Mioceno (menos recente), com cerca de 18\% de conchas recentes e Plioceno (mais recente) com mais de $40 \%$ de conchas recentes em sua fauna. Em 1854 a parte superior do Eoceno foi separada com a denominação de Oligoceno (pouco recente). Em 1839 Lyell chamou as camadas contendo
$70 \%$ de espécies de conchas recentes de Pleistoceno (o mais recente), que mais tarde foram unidas ao Recente (Holoceno), para constituir as duas séries do sistema Quaternário. Paleoceno foi introduzido mais recentemente na coluna estratigráfica, para incluir algumas camadas que antes eram supostas pertencerem ao final do Cretáceo.

\section{c. Causas das extinções em massa}

A partir da década de 80 vem sendo dada crescente atenção à possibilidade de a extinção em massa no limite $\mathrm{K}-\mathrm{T}$ ter sido causada pelo impacto, possivelmente no oceano, de um asteróide ou cometa. Pesquisadores da Universidade da Califórnia encontraram em Gubbio, na Itália, uma fina camada de argila, antiga de 65 milhões de anos, particularmente rica no elemento químico irídio, que é cerca de 10.000 vezes mais abundante em meteoritos rochosos que nos materiais crustais. Essa camada acha-se na passagem de camadas que contêm fósseis de dinossauros para outras acima, que não os possuem e pertencem ao Paleoceno Inferior. Alvarez et al. (1980) propuseram que o planeta foi atingido nessa ocasião por um asteróide com cerca de $10 \mathrm{~km}$ de diâmetro, ou cometa (Hsü 1980).

Numerosos cientistas concordam hoje que um grande objeto chocou-se com o planeta por ocasião da extinção dos dinossauros. Cerca de uma centena de anomalias de irídio são hoje conhecidas nesse limite. Admitindo-se que o bólido caísse no oceano abriria uma cratera com cerca de 200 $\mathrm{km}$ de diâmetro, afastaria a atmosfera em seu trajeto e formaria uma bola de fogo de alguns milhares de quilômetros, que ventos de centenas de quilômetros por hora espalhariam, queimando a vegetação e matando os animais terrestres. As águas oceânicas seriam revolvidas, provocando turbilhões que levariam águas da superfície ao fundo e deste elevariam águas frias pobres em oxigênio, com efeitos catastróficos para a vida. Tsunamis gigantes varreriam as costas em todo o mundo. A poeira escureceria a atmosfera durante meses, causando uma noite que inibiria a fotossíntese. Produzir-se-ia chuva ácida, e a camada de ozônio, afetada, permitiria a penetração da intensa radiação ultravioleta solar mortífera.

É fácil imaginar os efeitos dessa catástrofe para a vida, tal como na instigante simulação do fenômeno na abertura do filme Armageddon. Mas existem 
crateras que podem ter resultado de tão violento impacto? Arthur (1993) cita como candidatas a estrutura Manson em Iowa, USA, e a cratera de Chiksulub na península de Yucatán no sul do México, ambas com tectitos e idade no limite $\mathrm{K}-\mathrm{T}$. Outras duas parecem existir no norte do Canadá e na antiga União Soviética, mas há que se lembrar que o bólido teria mais chances de cair no oceano, que cobre área mais extensa do que a dos continentes, com a possibilidade de desaparecer a cratera devido a fenômenos de subducção das placas tectônicas.

A catástrofe do final do Cretáceo, embora extremamente severa, foi precedida de outras. A que aconteceu no final do Permiano foi provavelmente a mais devastadora de todas (Erwin 1996): cerca de $90 \%$ de todas as espécies marinhas, assim como dois terços das famílias de répteis e anfíbios, desapareceram durante os últimos milhões de anos do Permiano.

No decorrer do Terciário, a vegetação das terras emersas passou aos poucos a adquirir seus aspectos modernos, com as Angiospermas ocupando o lugar das Gimnospermas mesozóicas. Mudanças climáticas alteraram a distribuição geográfica das florestas. No mundo animal os invertebrados desde cedo atingiram o estado atual de sua evolução. Destacaram-se os foraminíferos, lamelibrânquios e gasterópodos, por sua abundância e diversidade. A evolução dos insetos acompanhou a grande diversificação da flora. O número de famílias de peixes e de aves teve grande aumento logo após o Cretáceo.

Com a destruição de quase toda a fauna reptiliana no intervalo $\mathrm{K}-\mathrm{T}$, os mamíferos, até então animais pequenos e pouco diferenciados, apresentaram um desenvolvimento explosivo desde o início do Terciário, ocupando o espaço deixado pelos répteis nos continentes, no mar e no ar, justificando considerar-se o Cenozóico como a Era dos Mamíferos, tal como o Mesozóico o foi dos Répteis. Incluíram, como estes, grandes animais marinhos e continentais, além de pequenos voadores.

No final do Terciário os primatas evoluíram para um animal inteligente que, no Quaternário, com seu alto poder para matar e conscientemente destruir o ambiente, tardiamente dotado da fala, tornou-se o principal causador de nova e crescente extinção em massa, que vem se processando desde o Pleistoceno: o Homem.

Modernos autores consideram o Homem, ademais, como importante agente geológico no planeta (Nir 1983, Hooke 2000, van Loon 2001).

\section{Métodos geocronológicos}

O termo Geocronologia foi utilizado pela primeira vez em 1893 por Williams para reunir as diferentes formas de investigação da escala de tempo em anos aplicáveis não só à evolução da Terra mas também à evolução de todas as formas de vida. Para essas determinações torna-se necessário um relógio geológico, ou seja, o conhecimento de um processo irreversível que seja governado pelo tempo, a uma taxa conhecida. A descoberta da radioatividade permitiu o nascimento da Geocronologia, pela datação radiométrica ${ }^{7}$. Na Geologia, o único processo que ocorre a uma taxa estatisticamente previsível e estável $^{8}$ é a desintegração radioativa.

\section{a. A descoberta da radioatividade}

A radioatividade foi detectada pela primeira vez há aproximadamente 100 anos atrás, com o uso de meios mecânicos. Tudo se associa a uma série de circunstâncias favoráveis que envolveram experimentos com sais de urânio. Parece que tudo começou com o vidreiro alemão Heinrich Geissler que se dedicou a construir vasos de pressão contendo eletrodos de metais que poderiam ser utilizados para estudar a transmissão de cargas elétricas através do vácuo. As experiências mostraram em 1855 a existência dos raios catódicos, somente explicados em 1897 por J. J. Thomson. Este considerou os raios como fluxos de elétrons, ou seja, partículas negativamente carregadas. $\mathrm{O}$ passo levou ao conhecimento da estrutura interna dos átomos e, conseqüentemente, trouxe um prêmio Nobel de Física para Thomson.

O conhecimento dos raios catódicos possibilitou ainda, de forma indireta, a descoberta da radioatividade. Becquerel, em 1880, ao expor cristais de sulfato duplo de urânio à luz ultravioleta obteve luminescência ${ }^{9}$; na época, os físicos verificaram que a propriedade era visível durante a passagem dos raios catódicos das paredes de vidro dos tubos. O fenômeno foi confirmado por Roëntgen,

7 Datação radiométrica é a medida da quantidade de tempo passado por meio de análises de minerais e rochas.

8 Radioatividade é o processo de desintegração espontânea de alguns tipos de átomos que ocorrem na natureza. Verifica-se em laboratório que a taxa média da desintegração radioativa espontânea não é afetada nem por aquecimento, resfriamento ou mesmo trocas referentes a pressão e estado químico.

9 Luminescência é a propriedade que certos materiais apresentam de emitir luz visível em resposta à excitação por outra fonte de energia. 
que provocou luminescência em um papel coberto de platicianeto de bário em 1895. A luminescência continuava, porém, enquanto o tubo de raios catódicos estivesse energizado. Aparentemente ele emitia uma radiação misteriosa que podia penetrar e ser impressa em papel preto - os famosos raios-X de Roëntgen. Becquerel, motivado pela descoberta, retomara seus estudos anteriores com os sais de urânio. Para verificar se estes eram responsáveis pela emissão de raios-X, recobriu uma chapa fotográfica com papel preto e colocou alguns cristais de sulfato de urânio em cima deste, expondo o pacote à luz solar. Os cristais emitiram uma radiação invisível que atravessou o papel preto e foi registrada na chapa fotográfica. A experiência, embora simples, mostrou que os sais de urânio e eventualmente até mesmo minerais de urânio poderiam emitir radiação contínua mesmo quando não expostos à luz solar.

A descoberta animou grande número de pesquisadores jovens como o casal Marie e Pierre Curie. Esta devotou-se à procura sistemática de outros elementos e compostos semelhantes aos utilizados por Becquerel e que emitissem radiação similar, tendo descoberto que minerais de $\mathrm{U}$ e $\mathrm{Th}$, conforme Becquerel já suspeitava, também emitem radiação, mais ativa que a dos sais destes elementos. Ao pesquisar com o minério da mina de Joachimsthal (Tchecoslováquia), o casal Curie conseguiu provar a idéia e descobriu dois novos elementos com propriedades semelhantes: Polônio (Po) e Rádio (Ra). O fenômeno recebeu o nome de radioatividade pelas emissões observadas a partir do Ra e rendeu o prêmio Nobel de Física de 1903 para o casal.

O efeito da descoberta na Geologia foi profundo, pois facilitava uma nova linha de pesquisa, visando medir a radioatividade das rochas.

A radioatividade gera calor nas rochas, pois é processo exotérmico, e também é um meio eficaz de medida da idade de minerais e rochas. A possibilidade foi percebida tanto por Rutherford como Boltwood, já em 1905. O primeiro propôs que se estimasse a idade da série de minerais de $\mathrm{U}$ a partir da quantidade de He neles acumulada; aplicara este método em inúmeros minerais de $\mathrm{U}$ e obtivera um valor aproximado de $500 \mathrm{Ma}$. Boltwood publicou a seguir os resultados das primeiras determinações de idade de três amostras de uraninita com base nas suas relações $\mathrm{U} / \mathrm{Pb}$. Os valores, entre 410 e 535 $\mathrm{Ma}$, considerados razoáveis, são hoje concordantes com as idades obtidas por técnicas mais modernas.
Joly (1908) reconheceu que certos halos observados em algumas amostras de rochas ao microscópio eram causados por minerais radioativos. Ele também mediu as concentrações de Th e Ra nos diferentes tipos de rochas e em 1909 publicou o livro intitulado Radioatividade e Geologia no qual sumariava suas conclusões. Destacava-se a idéia de que a radioatividade forneceria a energia requerida para a construção das montanhas.

A radiação ionizante descoberta pelos Curie levou Rutherford, que já havia estudado a ionização dos gases pelos raios-X, a efetuar um estudo desta natureza, porém com a radiação emitida pelo $\mathrm{Ra}$. Pouco tempo depois ele mostrara que a radiação era originada a partir das substâncias radioativas e consistia de três componentes denominados alfa (a), beta (b) e gama (g). O componente alfa, na realidade, é um núcleo do gás nobre Hélio (He). O beta foi identificado como sendo elétrons. Somente o raio gama mostrou ser uma radiação eletromagnética semelhante aos raios-X de Roëntgen.

A teoria da desintegração radioativa formulada por Rutherford e o químico Soddy diz que os átomos dos elementos radioativos se desintegram espontaneamente formando átomos de outros elementos e emitindo partículas alfa e beta. A desintegração radioativa é evento estatístico, pois não se pode prever nem a identidade de um átomo particular que irá se desintegrar nem o momento exato em que o evento ocorrerá. No entanto, a intensidade de radiação é proporcional ao número de átomos radioativos presentes. Os pesquisadores sugeriram ainda que a estrutura do átomo era formada por um núcleo (prótons) rodeado por uma coroa eletrônica, formada por elétrons. Soddy, em outro grupo de trabalho, reconheceu as séries do $\mathrm{U}$ e do Th, verificando que ambos possuíam diferentes taxas de desintegração. As novas formas resultantes dessas desintegrações foram identificadas como elementos químicos, cuja característica principal é a presença de átomos de Th, porém com pesos atômicos distintos. As diferentes amostras de Th existiriam na mesma posição do Th original na Tabela Periódica e constituiriam isótopos (em grego: mesmo lugar).

Vários pesquisadores dedicaram-se a procurar e caracterizar os isótopos. Após o término da Primeira Guerra Mundial, um deles, Aston, tentou construir equipamentos que confirmassem e caracterizassem os isótopos: os espectrômetros de massa. Recebeu o prêmio Nobel em 1922 pela descoberta de 212 dos 287 isótopos de ocorrência natural. 


\section{b. A revoluçãa no uso dos relógios geológicos}

"A enorme ampulheta, que mede a destruição das rochas na terra e a sua formação no fundo do mar, trabalha ininterruptamente."

Arthur Holmes (1923, p. 11)

Para estudar os problemas ligados à idade da Terra, Arthur Holmes começou medindo a composição isotópica do chumbo, na mesma época do aprimoramento dos espectrômetros, e evoluiu para novos métodos de datação utilizando o Th e o U presentes no chumbo. O livro The Age of the Earth, publicado por Holmes em 1923, mostra a importância da radioatividade no entendimento dos processos geológicos, além de propor a primeira escala do tempo geológico baseada em métodos radiométricos.

A datação radiométrica permitiu tratar numericamente o tempo. É difícil avaliar seu impacto nos conceitos geológicos devido à quantificação; não somente se aprimorou o conceito sobre a idade total da Terra, mas também foi possível datar amostras de rochas da Lua e fragmentos de meteoritos, revelando-se idades similares entre eles. A datação isotópica também abriu possibilidade para se determinar com rigor quantitativo as taxas dos processos atuantes no passado geológico. Finalmente, a Geocronologia permitiu estudar intervalos de tempo afossilíferos e subdividi-los.

\section{c. Isótopos estáveis e isótopos radioativos}

Na natureza são conhecidos isótopos instáveis e isótopos estáveis. Os instáveis ou radiogênicos resultam dos processos de desintegração radioativa. São particularmente interessantes para datação do tempo geológico pois podem ser aprisionados nos minerais. Sendo assim, pode-se fazer datação radiométrica de rochas que contenham elementos radioativos e, conseqüentemente, isótopos instáveis. Estes se originam a partir das transformações espontâneas, que envolvem a emissão de partículas ou de energia e que ocorrem no núcleo dos átomos instáveis (os chamados átomos-pai) onde estão os prótons e os nêutrons.

Os átomos podem se desintegrar de diferentes modos, transformando-se em formas de menor energia, que são os isótopos radiogênicos do elemento original. Os isótopos são designados por um número que representa a soma total de nêutrons e prótons existentes no seu núcleo. É o número de massa do elemento, normalmente escrito na porção

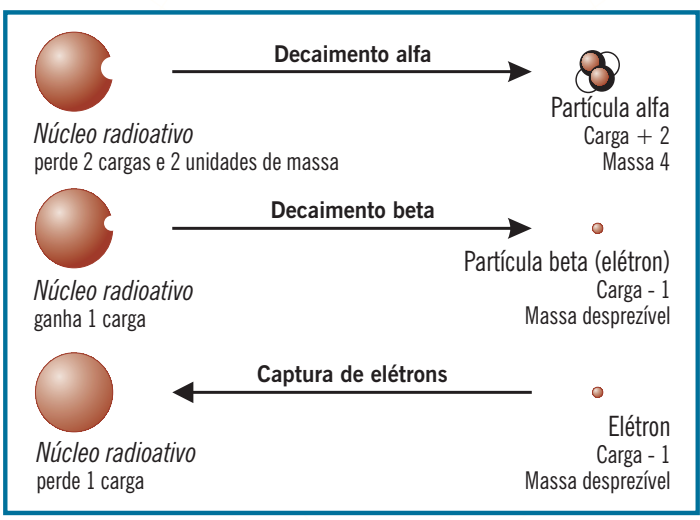

Figura 5 - Os três tipos de decaimento radioativo modificado de Eicher \& McAlester 1980). Na desintegração alfa (a) ocorre a perda, pelo núcleo do átomo-pai, de dois prótons e dois nêutrons; 0 número de massa decresce de quatro e o número atômico de dois. A desintegração beta consiste na emissão, pelo núcleo, de um elétron de alta velocidade, um de seus nêutrons se transforma em um próton e o número atômico aumenta de um. Na captura de elétrons, um próton do núcleo captura um elétron orbital e se transforma em um nêutron: o número atômico decresce de um. A desintegração beta e a captura de elétrons não mudam o número de massa

superior esquerda do símbolo químico do elemento (o urânio natural, por exemplo, é uma mistura dos isótopos ${ }^{238} \mathrm{U}$ e $\left.{ }^{235} \mathrm{U}\right)$. A representação é justificada pelo fato de que as emissões do núcleo de um isótopo radiogênico trocam a identidade do isótopo por aumentar ou diminuir o número de nêutrons presentes no núcleo.

Em geral, no processo de desintegração radioativa, o núcleo do elemento-pai pode emitir partícula alfa, beta ou ainda capturar um elétron quando da desintegração. Além disso pode simultaneamente emitir raios-gama (radiação eletromagnética mais energética do que raios-X). A desintegração alfa (a) consiste na perda, pelo núcleo do átomo-pai, de dois prótons e dois nêutrons; o número de massa decresce de quatro e o número atômico de dois. A desintegração beta ocorre quando o núcleo emite um elétron de alta velocidade, um de seus nêutrons se transforma em um próton e o número atômico aumenta de um. Na captura de elétrons, um próton do núcleo captura um elétron orbital e se transforma em um nêutron: o número atômico decresce de um. A desintegração beta e a captura de elétrons não mudam o número de massa (Fig. 5).

A desintegração radioativa envolve apenas o núcleo de um átomo-pai; a taxa não se altera quaisquer 
que sejam as condições físicas e químicas, como pressão, temperatura e soluções-tampão. Os átomos de um nuclídeo radioativo específico, qualquer que seja a sua idade, possuem cada um a mesma probabilidade de preservação ou desintegração. O processo é estatisticamente caótico e, por isto, pode-se estabelecer a desintegração por meio de uma constante de desintegração $(\mathrm{g})$ que indica a proporção de átomos radioativos existentes que se desintegrarão na unidade de tempo.

O número total de átomos para desintegrar-se será dado por $\mathrm{gN}$, onde $\mathrm{N}$ é o número total de átomos radioativos pais que estão no sistema. Desde que $\mathrm{N}$ decresce constantemente pela desintegração de uma dada amostra, o número real de átomos a se desintegrar decrescerá com cada intervalo sucessivo de tempo na proporção da redução do número de átomos radioativos pais sobreviventes. O tempo de vida de um elemento pai radioativo em um dado sistema não pode ser especificado, pois

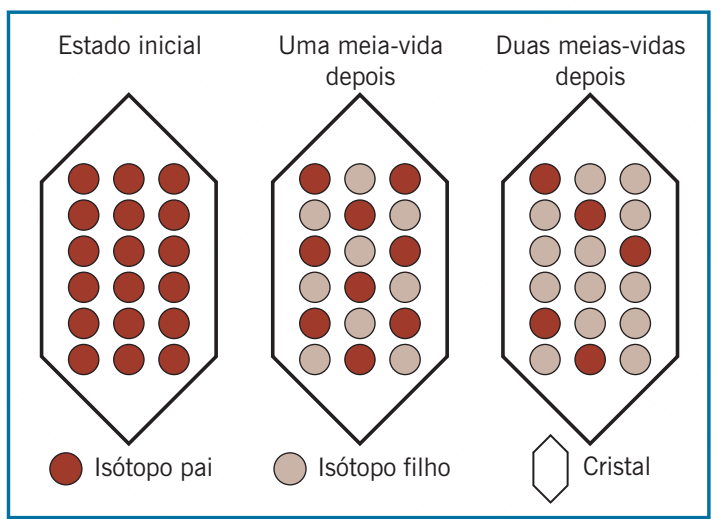

Figura 6 - Decaimento de um isótopo radioativo dentro de um cristal

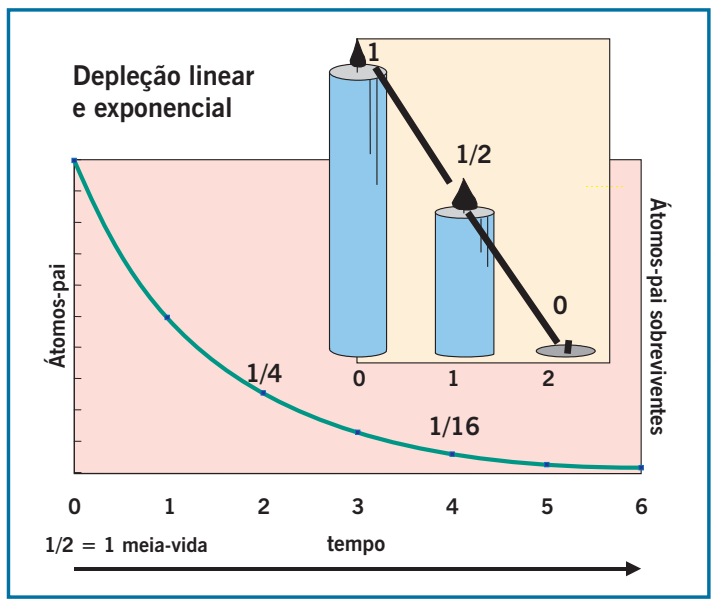

Figura 7 - Funções lineares e exponenciais (modificado de Eicher 1969) na teoria é considerado infinito. No entanto, é simples determinar o tempo de desintegração da metade dos átomos pais radioativos de determinado sistema, a chamada meia-vida.

Cada nuclídeo radioativo possui uma meiavida única, $\mathrm{t}_{1 / 2}$, que se relaciona à sua constante de desintegração. Isto é fundamental para a datação radiométrica pois os métodos utilizados têm por base a acumulação dos átomos-filho produzidos por um pai radioativo. Ao se formar, um mineral ou rocha contém somente o nuclídeo radioativo: admite-se que a quantidade de filhos radiogênicos seja igual a zero. Portanto, a razão filho/pai inicial é zero e a idade indicada também é zero. A desintegração progressiva de átomos-pais radioativos produz átomos-filhos radiogênicos, que ficam aprisionados em suas respectivas posições no retículo cristalino (Fig. 6).

Conhecendo-se a constante de desintegração do pai radioativo, necessita-se apenas medir no sistema a proporção de nuclídeos-filhos e pais ( $\mathrm{N}$ \% $\mathrm{N}^{t}$ ) de modo a calcular o tempo em que o sistema se originou (Fig. 7), em anos antes do presente.

O tempo, chamado de idade radiométrica do sistema, é calculado pela equação:

Idade $=\ln ($ átomos-filho/átomos-pai + 1) X 1/l

Como é um processo exponencial, pode ser expresso da seguinte forma:

$$
\lambda t=\ln \left(N^{\circ} / N^{t}\right)
$$

onde:

$$
\begin{aligned}
& \lambda=\text { constante de desintegração } \\
& N^{\circ}=\text { número de átomos do isótopo-filho no tempo }
\end{aligned}
$$

É importante fixar uma unidade de tempo que possa expressar a constante de desintegração característica de um isótopo particular. Neste caso utiliza-se a meia-vida $\left(t_{1 / 2}\right)$ que é o tempo requerido para que a metade da quantidade original de isótopo presente no sistema seja desintegrada:

$$
\begin{aligned}
& \lambda t_{1 / 2}=\ln 2 \\
& t 1 / 2=\ln 2 / \lambda=0,693 / \lambda
\end{aligned}
$$

Duas suposições são fundamentais: o sistema permaneceu fechado (nenhum átomo-pai ou filho foi adicionado ou removido do sistema quando este 
se originou) e nenhum átomo de nuclídeo-filho estava no sistema quando da sua formação. Muitos minerais e rochas satisfazem a essas condições, porém, algumas vezes, já existiam alguns nuclídeos-filhos no sistema. Como é possível determinar a concentração dos filhos originais que existiam no sistema, este valor pode ser então subtraído da quantidade total de nuclídeos-filhos para determinar a porção produzida somente pela desintegração radioativa.

Em 1931, quando os isótopos instáveis já eram razoavelmente bem conhecidos, Urey descobriu uma nova categoria, ou seja, os chamados isótopos estáveis ou naturais. Urey concentrou seus estudos iniciais no $\mathrm{H}$, pois outros pesquisadores já haviam sugerido que ele poderia ter isótopos de ocorrência natural. Os resultados iniciais da pesquisa confirmaram a presença de um isótopo do $\mathrm{H}$, por ele denominado de deutério pois deveria ter aproximadamente o dobro da massa do H. Algum tempo depois este mesmo pesquisador levantou a possibilidade de o O também apresentar isótopos estáveis e de ocorrência natural associados a processos de fracionamento. Assim foram descobertos os isótopos estáveis dos elementos $\mathrm{H}, \mathrm{O}, \mathrm{C}, \mathrm{N}$, bem como de outros. Estes, embora não utilizados diretamente como método de datação de rochas, podem dar informações variadas dos processos de ocorrência natural nos diferentes ambientes geológicos.

\section{d. Séries de desintegração e a datação de minerais e rochas}

A datação radiométrica dos diferentes minerais e rochas é obtida com o uso dos isótopos-pai e filho específicos para cada caso. Assim existem os métodos $\mathrm{K} / \mathrm{Ar}, \mathrm{Rb} / \mathrm{Sr}$ e $\mathrm{U} / \mathrm{Pb}$, entre outros. $\mathrm{Na}$ Tabela 1, são apresentados os principais isótopos utilizados em Geocronologia e a meia-vida característica para cada caso.

A escolha do método de datação a ser utilizado depende do material que queremos datar (rocha ou mineral), das características geológicas da região onde a amostragem foi realizada e da presença tanto do isótopo-pai como do isótopo-filho constituindo um sistema fechado. Existe possibilidade de se escolher entre um número cada vez maior de métodos radiométricos e as respostas obtidas por meio de cada um deles tem possibilitado posicionar no tempo os principais eventos da história geológica de determinada região, bem como o entendimento da evolução temporal da Terra (Tab. 2).
Tabela 1 - Principais isótopos utilizados em geocronologia

Isótopo-pai Isótopo-fillho Meia-vida (Ga)

\begin{tabular}{c|c|c} 
(Sm) Samário 147 & (Nd) Neodímio 143 & 106,0 \\
\hline (Rb) Rubídio 87 & (Sr) Estrôncio 87 & 48,8 \\
\hline (Th) Tório 232 & (Pb) Chumbo 208 & 14,0 \\
\hline (U) Urânio 238 & (Pb) Chumbo 206 & 4,5 \\
\hline (K) Potássio 40 & (Ar) Argônio 40 & 1,25 \\
\hline (U) Urânio 235 & (Pb) Chumbo 207 & 0,70 \\
\hline (Re) Rênio 187 & (Os) Ósmio 187 & 43,0 \\
\hline (Lu) Lutécio 176 & (Hf) Háfnio 176 & 35,0 \\
\hline (C) Carbono 14 & (N) Nitrogênio 14 & 0 - 50 000 a \\
\hline
\end{tabular}

( $\mathrm{Ga}=$ bilhões de anos e $\mathrm{a}=$ anos $)$

Tabela 2 - Algumas idades importantes

\begin{tabular}{c|c} 
Material & Idade (Ma) \\
Meteoritos & $4.300-4.600$ \\
\hline Rochas lunares & $3.500-4.200$ \\
\hline Idade da Terra (mineral) & $4.600-4.700$ \\
\hline Rochas mais antigas & $3.900-4.200^{10}$ \\
\hline
\end{tabular}

\section{e. Aparatos de laboratório e cuidados para se evitar contaminação}

A datação radiométrica é ferramenta indispensável nas ciências geológicas, pois permite extrair importantes inferências sobre a origem das rochas. O desenvolvimento da Geocronologia só foi possível com o aprimoramento das técnicas analíticas laboratoriais e também dos espectrômetros (equipamentos que medem as razões isotópicas). Isto porque o trabalho com isótopos radioativos, em função da meia-vida dos elementos (p. ex. ${ }^{87} \mathrm{Rb}$ tem meia-vida de $48,8.10^{9}$ anos), naturalmente irá envolver quantidades muito pequenas o que dificulta sua detecção (Fig. 8). Além disso, existe o

10 As rochas mais antigas da América do Norte fazem parte do complexo gnáissico de Acasta, próximo ao Lago Great Slave - 4,03 Ga - e as rochas supracrustais Isua no oeste da Groenlândia - 3,7 a 3,8 Ga. A idade mais precisa para a Terra $(4,54 \mathrm{Ga})$ é baseada em chumbo extraído de troilita dos meteoritos ferrosos de Canyon Diablo. Grãos do mineral zircão com idades $\mathrm{U}-\mathrm{Pb}$ de $4.4 \mathrm{Ga}$ foram recentemente encontrados em rochas sedimentares no centro-oeste da Austrália (Fonte: http://pubs.usgs.gov/gip/geotime/editors.html). 
problema da contaminação, ou seja, eventual acréscimo do elemento a ser dosado, não associado ao processo de desintegração radioativa.

A contaminação por $\mathrm{Sr}$, quando da aplicação do Método Rubídio-Estrôncio, pode ocorrer de diversas maneiras como, por exemplo, com cimento comum de construção civil. O cimento contém Ca que, por sua vez, tem Sr associado. A presença deste material no laboratório, mesmo em quantidades mínimas, acarretará contaminação por Sr e conseqüente problema com as idades determinadas.

A Geocronologia caracteriza-se pela necessidade de laboratórios super-limpos onde não haja possibilidade de contaminação e onde valores muito pequenos dos isótopos possam ser precisamente determinados. Com estes cuidados, razões isotópicas, que inicialmente propiciavam uma precisão da ordem de $0,2 \%$, passaram a ser medidas com precisão da ordem 1 para $10^{4}$ ou melhor. Métodos antes considerados como inviáveis tais como o ReOs e o Lu-Hf puderam ser utilizados de forma rotineira. Destaca-se ainda a melhoria na sensibilidade e precisão dos espectrômetros de massa, por meio de equipamentos multicoletores, análises por ionização térmica convencional, utilizando íons negativos ou ainda por ICP.

\section{f. Amostragem}

Outro fator muito importante é a perfeita escolha das amostras a serem datadas. Embora existam grandes diferenças entre os métodos de datação radiométrica bem como uma enorme variedade de materiais datáveis, podem ser feitas algumas considerações gerais sobre os problemas de amostragem.

Inicialmente, os pontos de amostragem e as amostras devem ser precisamente selecionados bem como a definição de qual método deverá ser aplicado e como os resultados deverão ser avaliados. Com essa base poderemos definir se trabalharemos com amostras do tipo rocha total, minerais separados (frações) ou ambas as formas. O tipo e a quantidade de amostra dependem do método a ser empregado, mas sempre é interessante repetir-se a análise ou complementá-la com outro tipo de dados (como, por exemplo, análise química). A escolha das amostras inclui ainda preferencialmente a seleção de material não alterado e representativo da área a ser analisada. Torna-se ainda fundamental que todos os aspectos que possam afetar de alguma forma a datação radiométrica (tectônica, posição estratigráfica, processos diagenéticos e, ou, metamórficos, intrusões etc.) sejam previamente conhecidos.

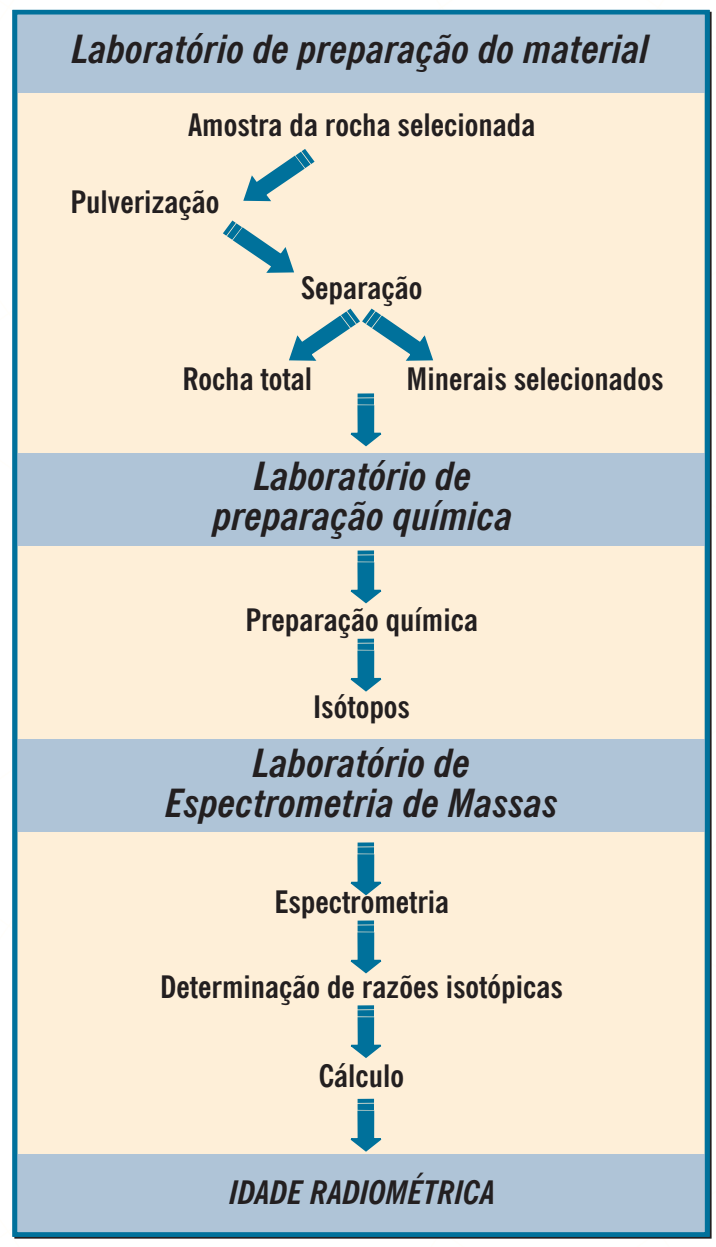

Figura 8 - Etapas principais na determinação geocronológica

\section{g. Exemplos de métodos muito usados}

\section{Rubídio-Estrôncio}

O Método Rubídio-Estrôncio permite a datação de rochas muito antigas, incluindo amostras de rochas lunares (coletadas pelas missões Apolo) até rochas com poucos milhões de anos. É muito utilizado em Geocronologia, pela versatilidade. $\mathrm{O}$ $\mathrm{Rb}$ não é um elemento comum na natureza e não forma mineral isolado, ou seja, ocorre como impureza em minerais de $\mathrm{K}$, aos quais se associa devido à semelhança de raios atômicos.

O isótopo radioativo ${ }^{87} \mathrm{Rb}$ desintegra-se para o isótopo ${ }^{87} \mathrm{Sr}$, em um único passo e com meia-vida de aproximadamente 48,8 Ga. Encontra-se Rb em minerais potássicos como as micas, feldspatos potássicos, piroxênios, anfibólios e olivinas, entre outros. Nesses minerais também ocorre $\mathrm{Sr}$ em sua forma original, não radioativa $\left({ }^{86} \mathrm{Sr}\right)$ o qual deverá 
ser precisamente determinado como parte do processo de datação. Essa quantidade será subtraída quando do cálculo final da idade da amostra, para evitar erros, uma vez que não foi originada pela desintegração do ${ }^{87} \mathrm{Rb}$ contido.

O Sr original sempre contém ${ }^{86} \mathrm{Sr}$ não-radiogênico, que é facilmente detectado. Inicialmente, $\mathrm{a}$ análise de uma amostra pobre em Rb permite determinar a razão ${ }^{87} \mathrm{Sr} /{ }^{86} \mathrm{Sr}$ que se mantém no material a ser datado; uma vez que a quantidade de ${ }^{86} \mathrm{Sr}$ na amostra não muda com o passar do tempo, procura-se em seguida uma amostra rica em $\mathrm{Rb}$ pois precisamos conhecer o valor do ${ }^{86} \mathrm{Sr}$ (Fig. 9). Conhecendo-se a relação inicial ${ }^{87} \mathrm{Sr} /{ }^{86} \mathrm{Sr}$ da amostra, podemos determinar a quantidade de ${ }^{87} \mathrm{Sr}$ que é original e aquela que é proveniente da desintegração do ${ }^{87} \mathrm{Rb}$. A idade é então calculada pela relação filho/pai radioativo. É uma idade convencional, ideal para rochas com minerais excepcionalmente ricos em $\mathrm{Rb}$.

Como isto nem sempre é possível ou surgem dúvidas quanto ao real valor do ${ }^{87} \mathrm{Sr}$, original, procura-se utilizar o Método da Isócrona. Para aplicação são necessárias várias amostras de rochas cogenéticas ${ }^{11}$

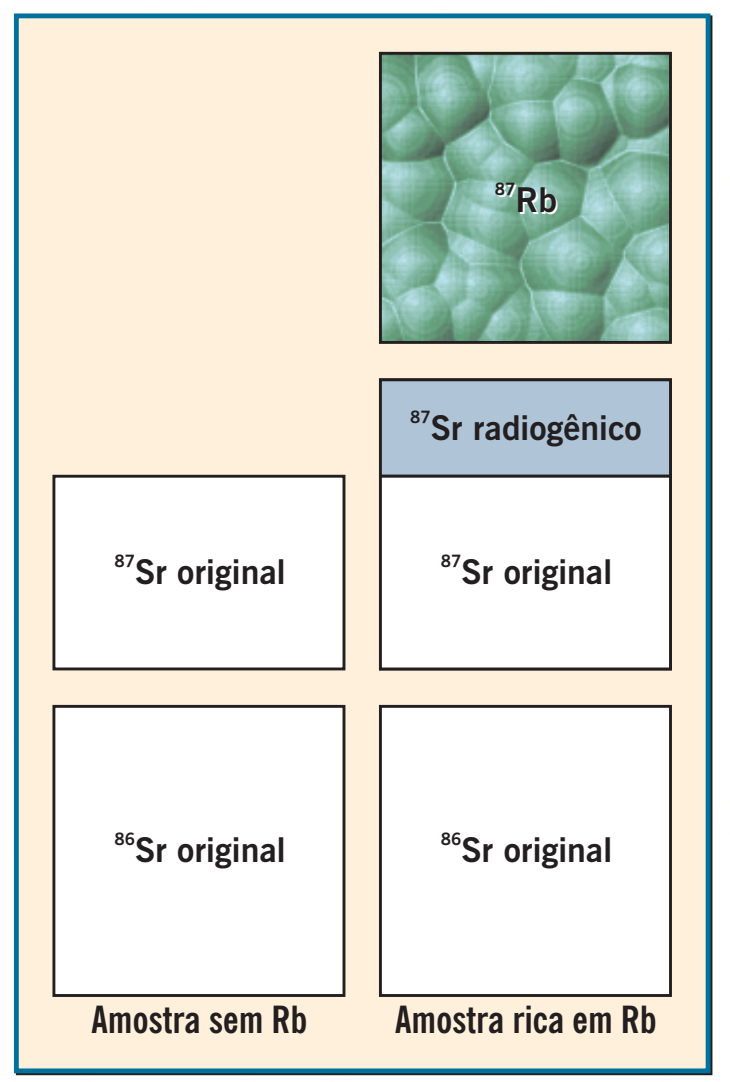

Figura 9 - Relações isotópicas da razão ${ }^{87} \mathrm{Sr} / 86 \mathrm{Sr}$ no Método $\mathrm{Rb} / \mathrm{Sr}$ (baseado em Eicher \& McAlester 1980) que contenham diferentes teores de $\mathrm{Rb}$. Com isto torna-se possível a montagem da isócrona (Fig. 10).

Supõe-se que, no tempo em que as amostras cogenéticas foram formadas (tempo zero inicial), as razões ${ }^{87} \mathrm{Sr} /{ }^{86} \mathrm{Sr}$ eram as mesmas para todas, mas era variável o conteúdo em Rb. Caso tivéssemos oportunidade de analisar estas amostras de rocha logo após a sua formação conseguiríamos plotá-las segundo uma linha horizontal no gráfico da figura que mostra a relação ${ }^{87} \mathrm{Sr} /{ }^{86} \mathrm{Sr}$ como eixo das ordenadas e a razão ${ }^{87} \mathrm{Rb} /{ }^{86} \mathrm{Sr}$ como abcissa. Com o passar do tempo, o conteúdo de ${ }^{87} \mathrm{Rb}$ deve decrescer gradualmente, pois é transformado em ${ }^{87} \mathrm{Sr}$, o qual deverá aumentar proporcionalmente nas amostras. No diagrama da figura 10 tal situação é acompanhada pelo deslocamento da linha A-A', que irá reproduzir o comportamento atual das amostras cogenéticas (B-B'). A série de amostras continua a definir uma linha reta, cuja inclinação em relação à reta horizontal inicial deve aumentar sistematicamente com o tempo. A linha assim definida é a isócrona e a inclinação atual indica a idade radiométrica da rocha. Além disso, o ponto onde a isócrona intercepta o eixo das ordenadas nos indica a razão ${ }^{87} \mathrm{Sr} /{ }^{86} \mathrm{Sr}$ inicial do sistema.

\section{Urânio-Chumbo em zircões}

O Método Urânio-Chumbo, embora conhecido há bastante tempo, somente agora vem tendo aplicação crescente, especialmente na datação de minerais isolados. $\mathrm{O}$ avanço resulta da melhoria da capacidade analítica dos laboratórios que podem trabalhar em condições de alta limpeza, conseguindo resolução para amostras com até algumas partes por milhão desses elementos.

Os minerais que contêm U como componente principal são raros na natureza, porém minerais que contêm este elemento em quantidades-traço ${ }^{12}$ são comuns, o que os torna particularmente indicados para aplicação do Método U-Pb. O mineral mais indicado neste caso é o zircão (silicato de zircônio, $\mathrm{ZrSiO}_{4}$ ) que contém aproximadamente $0,1 \%$ em urânio e ocorre em rochas de diferentes idades, sempre em pequenas quantidades.

Todo Urânio de ocorrência natural contém não só o ${ }^{238} \mathrm{U}$ radioativo mas também o ${ }^{235} \mathrm{U}$, sempre numa relação de 138:1. O ${ }^{238} \mathrm{U}$ se desintegra para o ${ }^{206} \mathrm{~Pb}$ e o ${ }^{235} \mathrm{U}$ para o ${ }^{207} \mathrm{~Pb}$. Os dois elementos são utilizados para determinação de idades geológicas;

\footnotetext{
11 Significa que tiveram uma mesma origem.
}

12 Quantidades muito pequenas. 
no entanto, em função da alta mobilidade química do U em ambientes oxidantes, análises em amostras de rocha total efetuadas com o Método U-Pb são problemáticas. Isto fez com que a metodologia recebesse grande impulso na aplicação a minerais isolados.

Os minerais com urânio e que se prestam para aplicação do Método U-Pb, em geral, também contêm chumbo original, de tal forma que a idade radiométrica poderá exceder a idade real. $\mathrm{O}^{204} \mathrm{~Pb}$ não é produzido pela desintegração radioativa, sendo então um elemento-chave para a detecção da quantidade de chumbo original. Se é detectado no mineral o ${ }^{204} \mathrm{~Pb}$, que constitui uma fração do chumbo presente, então os outros isótopos como o ${ }^{206} \mathrm{~Pb}$ e o ${ }^{207} \mathrm{~Pb}$ também deveriam estar presentes quando da formação do mineral. A composição isotópica do chumbo comum pode ser obtida a partir de amostras que sejam pobres em urânio, à semelhança do que é feito no Método Rb-Sr. Assim, a quantidade do ${ }^{204} \mathrm{~Pb}$ pode ser utilizada para calcular as quantidades de ${ }^{206} \mathrm{~Pb}$ e do ${ }^{207} \mathrm{~Pb}$ originais, de forma que possam ser subtraídos quando do cálculo da idade radiométrica.

Depois deste procedimento, as idades obtidas pelas razões ${ }^{235} \mathrm{U} /{ }^{207} \mathrm{~Pb}$ e ${ }^{238} \mathrm{U} /{ }^{206} \mathrm{~Pb}$ devem concordar, mostrando que o mineral comportou-se como um sistema fechado. São chamadas idades concordantes e o valor que elas indicam é a idade radiométrica verdadeira. Isto pode ser observado no gráfico da figura 11, que é um diagrama concórdia.

Se as idades não concordam diz-se que são discordantes e, conseqüentemente, não representam a idade radiométrica verdadeira do mineral. O Método $\mathrm{U}-\mathrm{Pb}$ em zircões tem sido aplicado com sucesso para a determinação de idades radiométricas em rochas de diferentes composições e idades, amostras lunares e meteoritos.

\section{Samário-Neodímio}

O Método Samário-Neodímio teve seu desenvolvimento ligado a pesquisas visando a datação de amostras lunares e de meteoritos.

O Sm e o Nd são elementos que possuem baixa mobilidade química quando comparados aos demais elementos, principalmente os alcalinos. Além disso, inúmeros estudos demonstraram que, mesmo quando a rocha se encontra visivelmente alterada e/ou metamorfizada, não há interferência na relação $\mathrm{Sm} / \mathrm{Nd}$. Assim, o Método torna-se muito interessante pois pode ser aplicado em situações onde a utilização das demais metodologias é restrita. Destaca-se que as idades para $\mathrm{Sm}-\mathrm{Nd}$ podem

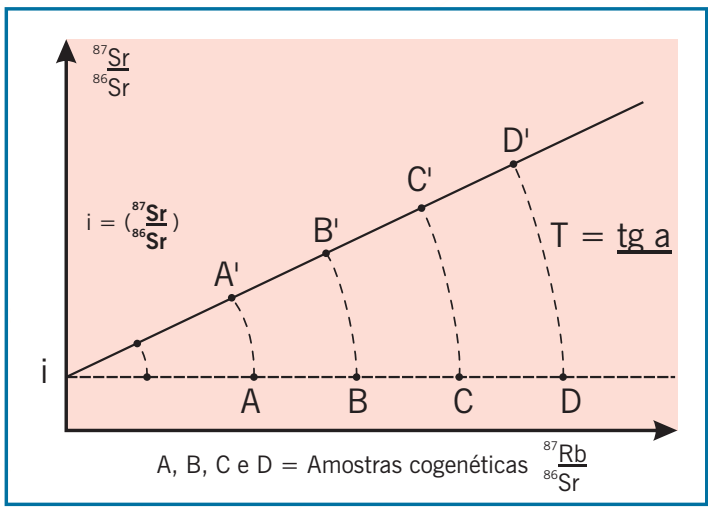

Figura 10 - Montagem da isócrona do Método $\mathrm{Rb} / \mathrm{Sr}$

Tabela 3 - Isótopos dos elementos químicos Samário e Neodímio (Geyh \& Schleicher 1992)

\begin{tabular}{c|c} 
Elemento & Isótopos \\
\hline $\mathrm{Sm}$ & ${ }^{144} \mathrm{Sm},{ }^{147} \mathrm{Sm},{ }^{148} \mathrm{Sm},{ }^{149} \mathrm{Sm},{ }^{150} \mathrm{Sm},{ }^{152} \mathrm{Sm},{ }^{154} \mathrm{Sm}$ \\
\hline $\mathrm{Nd}$ & ${ }^{142} \mathrm{Nd},{ }^{143} \mathrm{Nd},{ }^{144} \mathrm{Nd},{ }^{145} \mathrm{Nd},{ }^{146} \mathrm{Nd},{ }^{148} \mathrm{Nd},{ }^{150} \mathrm{Nd}$ \\
\hline
\end{tabular}

ser obtidas em qualquer tipo de rocha, desde graníticas até ultrabásicas.

O Sm tem sete isótopos naturais (Geyh \& Schleicher 1992), indicados na Tabela 3. O ${ }^{147} \mathrm{Sm}$ e $\mathrm{o}^{148} \mathrm{Sm}$ decaem por emissão alfa para o ${ }^{143} \mathrm{Nd} \mathrm{e}^{144} \mathrm{Nd}$. A meia-vida do ${ }^{148} \mathrm{Sm}$ é muito curta ( $7 \times 10^{5}$ anos) para ter um significado geocronológico, mas o decaimento do ${ }^{147} \mathrm{Sm}\left(1.06 \times 10^{11}\right.$ anos) permite que seja utilizado para datação. De forma análoga ao Método $\mathrm{Rb}-\mathrm{Sr}$, podem ser construídas isócronas com as relações ${ }^{143} \mathrm{Nd} /{ }^{144} \mathrm{Nd}$ e ${ }^{147} \mathrm{Sm} /{ }^{144} \mathrm{Nd}$. Supõese que, ao tempo da cristalização, amostras de rocha total cogenéticas a amostras de minerais com diferentes razões ${ }^{147} \mathrm{Sm} /{ }^{144} \mathrm{Nd}$ teriam o mesmo ${ }^{143} \mathrm{Nd}$ / ${ }^{144} \mathrm{Nd}$ inicial (entre 0.506 e 0.516 , de acordo com a idade da rocha). Amostras cogenéticas posicionamse em uma isócrona onde a inclinação é uma função da idade da amostra e onde a interceptação da isócrona no eixo "y" indica a razão inicial.

O cálculo de idades-modelos Sm-Nd tem por base o fato de que pode ser definida uma linha de evolução uniforme para a relação ${ }^{143} \mathrm{Nd} /{ }^{144} \mathrm{Nd}$ para a área-fonte de amostras de rochas da crosta continental e basaltos alcalinos (De Paolo \& Wasserburg 1976). Essa linha de evolução, que corresponde à do manto terrestre, tem por base a relação $\mathrm{Sm}-\mathrm{Nd}$ que é idêntica com a do reservatório condrítico uniforme $\left(\mathrm{CHUR}^{13}\right)$. Na verdade, se um magma é formado e separado a partir do CHUR em um determinado tempo, então sua razão ${ }^{143} \mathrm{Nd} /{ }^{144} \mathrm{Nd}$ (Ro) 


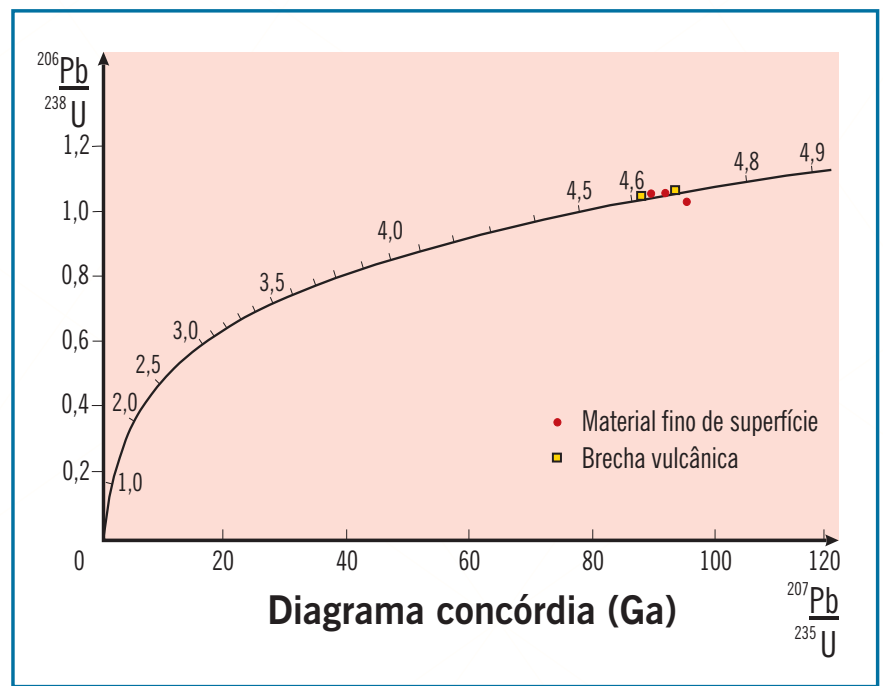

Figura 11 - Montagem da curva concórdia do Método U/Pb para amostras de rochas trazidas da Lua

é igual à do $\mathrm{R}_{\mathrm{CHUR}}$. Contudo, processos responsáveis pela formação do magma do manto ocasionam fracionamento químico do $\mathrm{Sm}$ e do $\mathrm{Nd}$ em relação à sua fonte. $\mathrm{O}$ fator de fracionamento é definido pela relação: $f_{\mathrm{Sm} / \mathrm{Nd}}=(\mathrm{Sm} / \mathrm{Nd})_{\text {amostra }} /(\mathrm{Sm} / \mathrm{Nd})_{\mathrm{CHUR}}$.

Então $f_{\mathrm{Sm} / \mathrm{Nd}}=1$ para a linha de evolução CHUR. Para a maior parte das rochas curstais, este fator é inferior a 1, o que significa que o $\mathrm{Nd}$ está se enriquecendo em relação ao Sm na crosta durante o fracionamento e separação do manto. Contudo, a geração da crosta continental ocasiona depleção ${ }^{14}$ de elementos nesse reservatório. Material do manto depletado tem uma linha de evolução diferente do CHUR (De Paolo 1981) e assim quando idadesmodelos são calculadas, os parâmetros para o manto depletado devem ser utilizados aos níveis daqueles de evolução do CHUR. O modelo assume que a relação $\mathrm{Sm} / \mathrm{Nd}$ somente será significativamente alterada por processos geológicos subseqüentes, como o metamorfismo ou processos ligados a erosão, desde que o sistema $\mathrm{Sm} / \mathrm{Nd}$ tenha funcionado como um sistema fechado. Com isto torna-se possível o estabelecimento de uma linha a partir das razões atuais ${ }^{143} \mathrm{Nd} /{ }^{144} \mathrm{Nd} \mathrm{e}{ }^{147} \mathrm{Sm} /{ }^{144} \mathrm{Nd}$ que, ao interceptar-se com a linha de evolução do CHUR, indicará uma idade modelo para o tempo de diferenciação dessa rocha a partir do manto.

13 CHUR - sigla derivada da expressão em Inglês: Chondritic uniform reservoir

14 Depleção significa perda, subtração gradual. Duarte (1997) refere-se a exaustão de uma jazida de petróleo.

\section{Carbono-14}

A utilidade do ${ }^{14} \mathrm{C}$ para datação radiométrica foi demonstrada inicialmente por Libby em 1947. Na realidade, este isótopo, ao contrário dos outros tradicionalmente utilizados para datação, faz parte de um grupo de nuclídeos radioativos de curta duração, originados na porção superior da atmosfera, onde partículas cósmicas de alta energia bombardeiam os núcleos do oxigênio e do hidrogênio ali presentes fazendo com que estes liberem átomos. Os átomos assim produzidos irão se chocar com átomos de nitrogênio - também encontrados nas porções elevadas da atmosfera - resultando na formação do ${ }^{14} \mathrm{C}$, cuja meia-vida é de aproximadamente 5.730 anos.

O radiocarbono produzido é oxidado para a forma de dióxido de carbono $\left(\mathrm{CO}_{2}\right)$ e passa a fazer parte da atmosfera e, eventualmente, da hidrosfera (Fig. 13). Assim, pode entrar no ciclo geral do carbono na Terra como também pode ser dissolvido nos oceanos, precipitado em associação com os minerais carbonáticos ou utilizado pelos diferentes animais e plantas.

Os seres vivos acham-se em equilíbrio com a atmosfera e o dióxido de carbono radioativo é absorvido e usado pelas plantas, entrando finalmente na cadeia alimentar e no ciclo do carbono. As pequenas quantidades de ${ }^{14} \mathrm{C}$ radioativo passam a fazer parte da estrutura dos animais, plantas e minerais propiciando-nos uma ferramenta extremamente útil para datar com precisão os últimos 50.000 anos da história da Terra (Tab. 4), assumindo-se que a taxa de produção de Carbono-14 (e portanto a quantidade de raios cósmicos que atingem a Terra) tenha sido constante durante os últimos 70.000 anos. Este limite relaciona-se ao fato de que, após a morte do organismo que incorporou ${ }^{14} \mathrm{C}$, este não é mais adquirido (Fig. 13) e, com o tempo, vai progressivamente sendo desintegrado para ${ }^{14} \mathrm{~N}$. Como os valores são muito pequenos é quase impossível a medição direta dos isótopos. Neste caso, opta-se pela contagem da atividade de emissão beta do espécime a ser datado e sua comparação com um padrão cuja atividade seja muito bem conhecida.

O número de emissões em um dado período de tempo é proporcional ao número de átomos do ${ }^{14} \mathrm{C}$ ainda presentes na amostra; quanto mais antigo, 
Tabela 4 - Limites usuais de detecção de alguns métodos

\begin{tabular}{c|c|c}
\multicolumn{2}{c}{ Método } & \multicolumn{2}{c}{$\begin{array}{c}\text { Aplica-se a intervalos } \\
\text { da ordem de (anos) }\end{array}$} \\
\cline { 2 - 3 } $\begin{array}{c}\text { Análise de ciclos de } \\
\text { crescimento de árvores }\end{array}$ & $\begin{array}{c}\text { Ciclos anuais e das } \\
\text { manchas solares }\end{array}$ & 3.000 \\
\hline $\begin{array}{c}\text { Análise de estratos } \\
\text { argilosos }\end{array}$ & $\begin{array}{c}\text { Ciclos anuais, das manchas } \\
\text { solares e de precessão de equinócios }\end{array}$ & 15.000 \\
\hline Carbono-14 & Matéria orgânica morta & 30.000 - 50.000 \\
\hline Métodos geológicos & $\begin{array}{c}\text { Velocidades admitidas de processos } \\
\text { como intemperismo, erosão etc. }\end{array}$ & $\begin{array}{c}\text { Sob restrições, a todos } \\
\text { os períodos geológicos }\end{array}$ \\
\hline Datação por U-Pb \\
e outros & $\begin{array}{c}\text { Decaimento radioativo de elementos } \\
\text { encontrados em rochas e minerais }\end{array}$ & $\begin{array}{c}\text { Todos os períodos } \\
\text { geológicos }\end{array}$ \\
\hline
\end{tabular}

menor deve ser essa atividade, o que nos limita ao valor máximo datável de 50.000 anos. O Método ${ }^{14} \mathrm{C}$ é utilizado para datação de matéria orgânica, madeira, carvão, ossos, turfa e artefatos como roupas e cerâmicas, além de conchas e calcários recentes.

\section{h. Outros métodos de determinação de idades: exemplo dos traços de fissão}

Diversos métodos de determinação radiométrica de idades de rochas acham-se hoje bem desenvolvidos e são aplicados a diferentes situações e ambientes geológicos. Uma revisão abrangente acha-se em Dickin (1995) e Attendorn \& Bowen (1997). Dentre eles, o Método dos traços de fissão baseia-se na fissão do $U$, que resulta no aparecimento de 2 fragmentos, um mais leve e outro mais pesado, na liberação de nêutrons e energia. Os fragmentos resultantes desta fissão recebem energia cinética e, graças a forças repulsivas coulombianas, irão adquirir movimentos em sentidos opostos. Os fragmentos ionizados, ao se deslocar através da estrutura de determinados sólidos isolantes ou semi-condutores provocam o aparecimento de defeitos (sob a forma de "trilhas") que recebem o nome de traços latentes.

Os traços latentes são facilmente visíveis com o microscópio eletrônico. No entanto, ataques químicos específicos melhoram a visualização dos traços pois permitem ampliar seus tamanhos. Com isto, os traços tornam-se visíveis ao microscópio óptico sendo então denominados traços de fissão. A etapa seguinte é a contagem dos traços aumentados (ou anotação da densidade de traços em uma dada área). O número de traços por unidade de área é uma função da idade do material e da concentração de urânio.
A técnica é especialmente útil para alguns minerais específicos como a apatita e o zircão, mas pode ser empregada na datação de micas, tectitos naturais e sintéticos (artificiais) e vidro. Os traços de fissão apresentam importante propriedade que é o seu "apagamento", ou seja, o desaparecimento gradual quando submetidos a determinadas temperaturas. Assim, os traços de fissão também permitem a obtenção de idades aparentes, relacionadas à sua reorganização quando estiveram submetidos a reaquecimento (idades de eventos térmicos).

\section{Como decifrar o registro das rochas? 0 atualismo}

É importante salientar o tema da uniformidade no comportamento da natureza, idéia fundamental, embora aparentemente simples. Leonardo da Vinci, no século XVII foi o primeiro a formulá-la, ao deixar implícito que só se poderia comprovar sua Lei da Superposição por meio de analogias com o presente geológico. Hutton, mais tarde, propôs o uniformitarismo da natureza, nas três edições conhecidas de sua obra "Theory of Earth, with proofs and illustrations", de 1793. Em uma delas, ele afirmou:

"O homem percebe com prazer a ordem e a regularidade com que se apresentam as obras da natureza, em vez do natural desgosto ante a desordem e confusão. Se a pedra que hoje cai, amanhã se alçasse, seria o fim da filosofia natural, nossos princípios fracassariam e não continuaríamos investigando as regras da natureza segundo nossas observações (...)";

Na passagem para o século XIX, Playfair (1802) divulgou e aplicou mais claramente a teoria. 


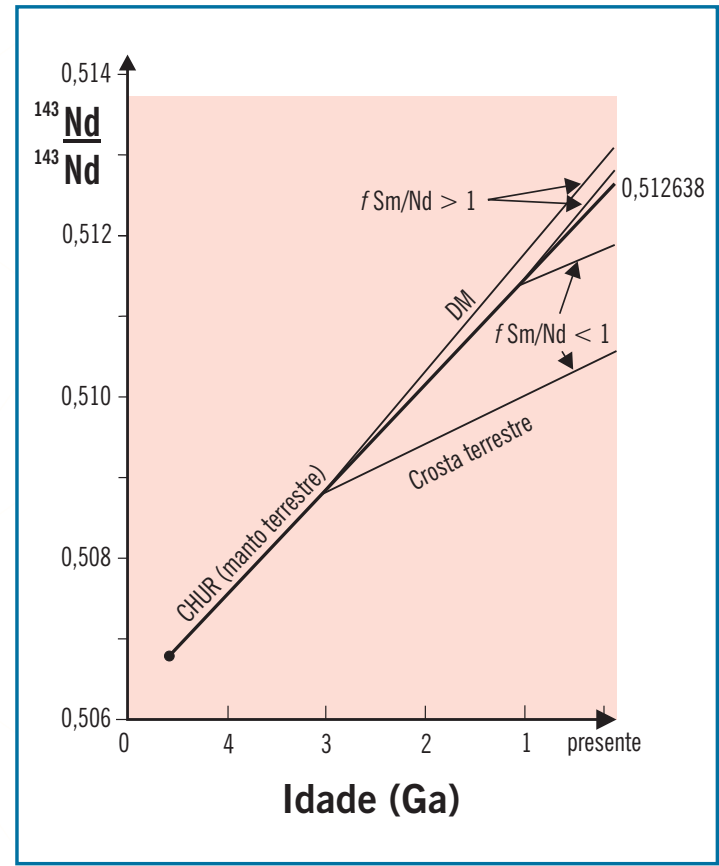

Figura 12 - Evolução da razão isotópica do Neodímio desde a condensação da Terra, no tempo $t_{\text {Terra. }}$ A taxa de aumento da relação ${ }^{143} \mathrm{Nd} /{ }^{144} \mathrm{Nd}$ de um reservatório ou unidade de rocha depende da razão $\mathrm{Sm} / \mathrm{Nd}$ naquele reservatório ou unidade de rocha; para a Terra toda, assume-se que essa taxa seja condrítica (CHUR). As duas linhas de evolução correspondem a dois reservatórios separados a partir de CHUR, cuja evolução pode ser esclarecida a partir do estudo da relação $f_{\mathrm{Sm} / \mathrm{Nd}}<1$ ou $f_{\mathrm{Sm} / \mathrm{Nd}}>1$ (modificado de Geyh \& Schleicher 1992)
Embora tenha sido grande divulgador das idéias de Hutton, coube a Lyell, entre 1830 e 1833, consagrar definitivamente o Uniformitarismo como um Princípio do pensamento geológico.

\section{a. 0 Uniformitarismo e o Atualismo}

Hutton e Lyell propõem o uniformitarismo da natureza pelos pontos de vista das causas, dos processos e dos efeitos. Em 1897, Sir Archibald Geikie sintetizou as idéias uniformitaristas na expressão tida como a mais radical de todas:

\section{"O presente é a chave do passado".}

Gretener (1984) destaca que a proposição reflete a "atitude arrogante do recém-chegado, Homo sapiens". Nem Hutton ou Lyell ousaram tamanha generalização sobre a uniformidade da Natureza (Carneiro et al. 1994). Durante muito tempo o enunciado implicou, para muitos, que (a) as leis naturais seriam invariáveis no tempo, (b) os mesmos processos que atuam hoje também ocorreriam no passado e (c) os eventos geológicos aconteceriam com velocidade uniforme.

As objeções feitas pelo precursor da termodinâmica, William Thomson, à idéia de abismo do tempo estenderam-se à idéia de uniformitarismo absoluto da Natureza. Pela dissipação de energia e mudanças nas condições naturais, a Terra não poderia comportar-se como um moto-perpétuo; ao contrário, segundo ele, pela $2^{\mathrm{a}}$ lei da termodinâmica a ação

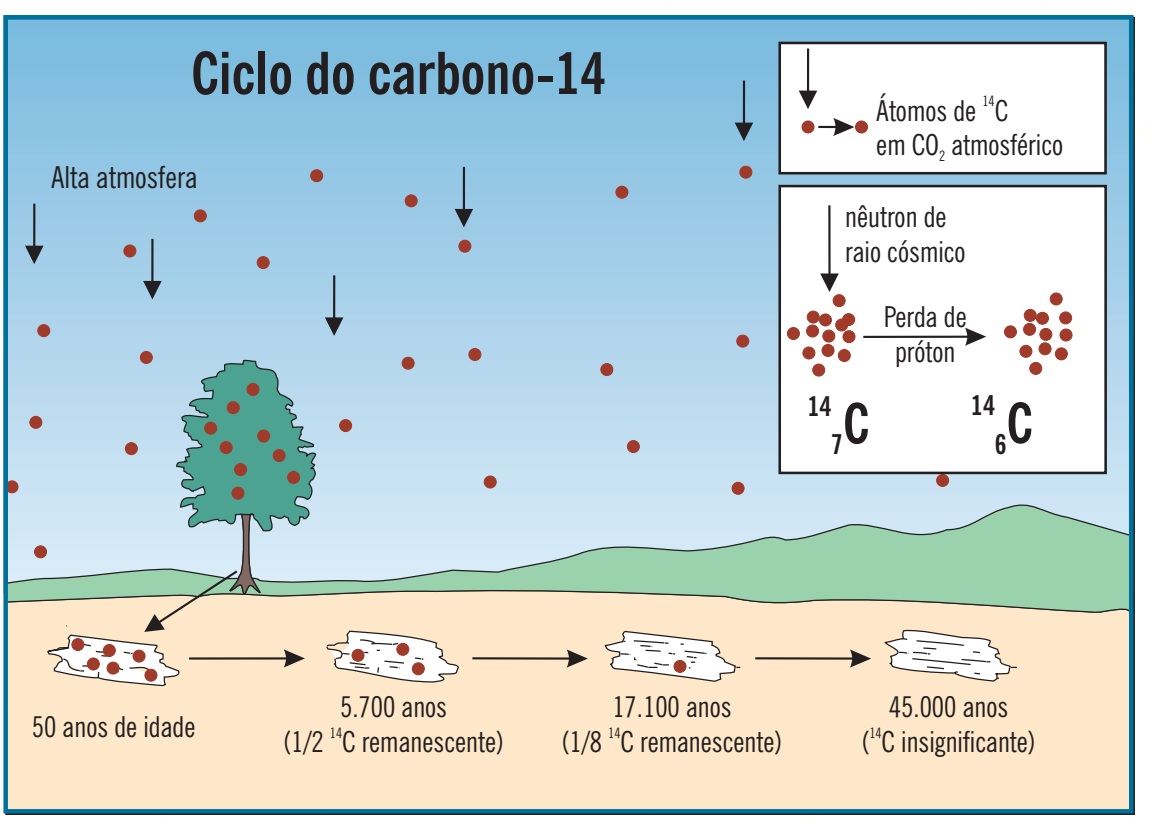

Figura 13 - Formação do isótopo radioativo ${ }^{14} \mathrm{C}$, pelo bombardeio de átomos de nitrogênio por raios cósmicos. 0 isótopo ${ }^{14} \mathrm{C}$ entra na molécula de $\mathrm{CO}_{2}$ e acaba incorporado a sedimentos carbonosos e restos orgânicos (modificado de Eicher \& McAlester 1980) 
natural seria irreversível, contrariando a repetição uniforme dos eventos naturais ao longo do tempo. Uma tempestade de críticas assolava, no início do século XX, o princípio fundamental da Geologia. Diante das objeções no aspecto da energia, as velocidades dos processos não poderiam ter-se mantido uniformes durante o tempo geológico.

Ainda que a descoberta da radioatividade como fonte de calor endógeno na crosta afastasse as restrições, no lado quantitativo dos processos, o avanço do conhecimento geológico trouxe novas restrições, agora qualitativas, às mudanças radicais de condições do ambiente geológico terrestre ao longo do tempo. As mudanças na composição da atmosfera e mesmo o aparecimento ou expansão da vida, por exemplo, poderiam ter provocado a extinção de alguns processos e surgimento de outros. Novas causas, produzindo novos resultados. Outra ressalva é que mesmas forças, atuando em configurações distintas de um mesmo material, poderiam produzir, inevitavelmente, resultados diversos.

O conjunto de objeções ao enunciado clássico do princípio pode ser resumido em duas idéias (Carneiro et al. 1994):

A. novas condições (em quantidade e qualidade) gerariam novas causas, novos processos e novos resultados;

B. mesmas causas atuando em configurações diversas gerariam resultados diferentes.

Tais objeções levam-nos a indagar sobre o que, afinal, restou do princípio do uniformitarismo tal como foi concebido originalmente por Hutton e Lyell, no século passado?

É possível distinguir quatro proposições no enunciado (Gould 1965, 1967):

a) a uniformidade das leis: as leis da natureza são invariáveis, no espaço e no tempo;

b) a uniformidade dos processos terrestres (atualismo): os eventos geológicos do passado envolveram processos de natureza essencialmente igual à dos que atualmente ocorrem;

c) uniformidade de velocidades (gradualismo): os processos operariam com idênticas velocidades, ainda que extremamente lentas e quase imperceptíveis aos sentidos humanos;

d) uniformidade de condições (não-direcionalismo): os ciclos naturais seriam intermináveis e a Terra, um lugar em constante mudança.

A primeira proposição relaciona o comportamento da Natureza à constância das leis físicas, mas não é peculiar ao uniformitarismo nem à Geologia, pertencendo ao domínio das ciências físicas. É plenamente aceito que as leis que governam os fenômenos terrestres sejam imutáveis (proposição "a"): trata-se de ponto de partida (ou seja, um princípio) para se realizar ciência. Portanto, subsiste a idéia de uniformidade no aspecto dos fenômenos físicos.

A segunda proposição é também generalizadamente aceita pois os processos terrestres atuais ocorreriam da mesma maneira (mas não necessariamente com a mesma intensidade) desde o passado (proposição "b"). As proposições "a" e "b" tratam daquilo que permanece, sob quaisquer circunstâncias, invariável no tempo e no espaço; expressam a regularidade (por exemplo, a lei da gravidade, as leis da termodinâmica etc.).

As duas últimas, porém, foram profundamente abaladas, por envolverem fatos singulares, impossíveis de se estudar sob a ótica estrita do uniformitarismo. A terceira e quarta proposições foram rejeitadas graças a aspectos da natureza que variam com as circunstâncias, ou seja, fatores contingentes ou históricos. Não persistem em termos físicos, pois inúmeros fatores modificaram-se ao longo do tempo, como a duração dos dias do ano ou a intensidade e natureza da radiação solar. Os aspectos singulares do uniformitarismo não constituem princípios da ciência histórica e tampouco da ciência física.

Sintetizando o problema, Gould (1967) distinguiu dois tipos de uniformitarismo:

- Uniformitarismo substantivo, que engloba as quatro proposições referidas. Segundo o autor, uma visão do comportamento da Natureza modernamente inaceitável.

- Uniformitarismo metodológico, que engloba somente as duas primeiras e ficou conhecido como Atualismo. Para as ciências físicas isso pode ser um princípio, mas para a ciência histórica não passa de um método, ou seja, é um dos métodos históricos em Geologia, que atende à noção de simplicidade.

O Atualismo tem especial importância na Geologia, porém é apenas um dos métodos históricos. Como método da Geologia, envolve aplicação de raciocínio indutivo e de analogias para o estudo dos fenômenos do passado, além de depender das pistas obtidas do presente. O exemplo dos corais é típico: sabemos que atualmente os recifes de corais crescem em águas tropicais, dentro de um espectro muito restrito de tolerâncias, e podemos assumir que formas comparáveis viveram sob condições muito similares no passado, mas persiste a evidente restrição de que os corais possam ter mudado seus hábitos com o passar do tempo (Ager 1963, p. 33). 


\section{b. 0 gradualismo e a noção de mudança pontuada}

O gradualismo proposto por Lyell (proposição "c") ainda que consiga explicar alguns fatos geológicos, é demasiadamente restritivo e não permite explicar todas as mudanças na história física e biológica da Terra. O catastrofismo, em suas recentes versões, vem sendo retomado por autores que buscam desligá-lo do forte compromisso com a idéia anterior de "criacionismo científico".

Gretener (1984) destaca a importância dos processos episódicos em geologia, quando comparados aos processos contínuos; assinala ainda que o termo "catastrofismo" possui a conotação de "desastre", dada por "imagens de destruição e escombros" (Gretener op. cit., p. 85), e prefere o termo "pontuação", proposto por Gould (1977, apud Gretener 1984, p. 81), para referir-se à natureza descontínua dos processos episódicos.

O conceito de mudança pontuada (punctuational change), da moderna geologia, pertence a uma visão "pluralista" da natureza: a mudança é marcada por episódios curtos que quebram o equilíbrio anterior e rapidamente estabelecem nova condição (Gould 1984). O modelo enfatiza a estabilidade duradoura dos sistemas terrestres e, por outro lado, a concentração da mudança em momentos definidos. Um exemplo, dentre outros, seria o impacto de um asteróide com o planeta, possibilidade aceita hoje pela astronomia. A probabilidade de ocorrência de um evento raro, em geologia, embora possa ser extremamente baixa, jamais pode ser considerada nula. Assim, deve-se manter uma clara distinção entre as idéias de "impossível" e "improvável" (Gretener 1984, p. 79). Sob o ponto de vista geológico, tempestades, inundações, escorrega- mentos e outros fenômenos podem ser considerados agentes episódicos regulares (Tab. 4) e não são propriamente eventos raros, embora o possam ser para os padrões humanos.

Um evento raro depende de uma combinação ou conjugação especial de fatores que incluem tanto aqueles intrínsecos como os extrínsecos ao planeta. Para sintetizar as inúmeras evidências de mudanças rápidas em escala global entremeadas com longos intervalos de "monotonia", Gretener (1984) afirma que a "história da Terra revela longos períodos de tranqüilidade interrompidos por momentos de ação". Essa proposição seria coerente com a importância relativa dos processos episódicos; dentre eles, cabe atenção os chamados probabilidade de ocorrência seria da ordem de $95 \%$, para que ocorram pelo menos uma vez ao longo de intervalos de tempo muito distintos.

\section{Experimentos educativos e simulações}

A vasta bibliografia sobre métodos de determinação de idade radiométrica de rochas concentra-se em artigos especializados e compêndios científicos sobre idades das formações geológicas. Textos didáticos são mais escassos, sobretudo em Português, justificando um esforço adicional para facilitar a compreensão do tema Tempo Geológico pelos estudantes, que é complexo e integrador de vários outros conceitos da moderna Geologia, como: cronologia de eventos, duração, correlação, mudança geológica, fácies e sucessão de causas. Enumeramos acima aspectos fundamentais desses conceitos, mas cabe citar algumas abordagens didáticas disponíveis em publicações introdutórias ou artigos metodológicos.

Tabela 5 - Eventos e processos geológicos

\begin{tabular}{c|c|c|c} 
Eventos & $\begin{array}{c}\text { Probabilidade da ordem de } \begin{array}{c}95 \%, \\
\text { para ocorrer pelo menos uma vez } \\
\text { em certo número de anos }\end{array} \\
\text { Raros }\end{array}$ & 1 bilhão de anos & $\begin{array}{c}\text { Anos } \\
\text { Eventos que possam ter ocorrido muito } \\
\text { poucas vezes na história da Terra }\end{array}$ \\
\hline Ocasionais & 100 milhões de anos & $10^{8}$ & $\begin{array}{c}\text { Extinções em massa; } \\
\text { desaparecimento de espécies }\end{array}$ \\
\hline Recorrentes & 1 milhão de anos & $10^{6}$ & $\begin{array}{c}\text { Glaciações; Modificações, registradas } \\
\text { em fósseis, de fauna e flora }\end{array}$ \\
\hline Comuns & 1 mil anos & $10^{3}$ & $\begin{array}{c}\text { Episódios registrados na história } \\
\text { humana; eventos de chuvas intensas }\end{array}$ \\
\hline Regulares & 1 século & $10^{2}$ & Enchentes seculares \\
\hline
\end{tabular}




\section{a. Abordagens didáticas sobre "Tempo Geológico"}

Para Pedrinaci \& Sequeiros (1994), se uma pessoa demonstrar conhecimento preciso da idade da Terra, nomes e durações dos períodos geológicos, isso não bastará para concluir que ela construiu o conceito de tempo geológico. As idéias de cronologia relativa e de duração dos processos geológicos fazem parte dessa construção gradativa de conhecimento. Sequeiros et al. (1996) apresentam propostas de trabalho sobre o tema, em diferentes níveis de aproximação, para ajudar os estudantes a elaborar imagens mentais de fatos geológicos. Os quadros abaixo são alternativas, dentre muitas possíveis.

\section{b. Significados presentes no tema "Tempo Geológico"}

Atividades educacionais envolvendo Tempo Geológico são geralmente agradáveis, porque os temas são às vezes familiares ou próximos da realidade das pessoas. Entretanto, podem surgir pro- blemas de apreensão de conceitos, ao se tentar desenvolver abstrações mais complexas, especialmente para alunos de pouca idade ou baixa escolaridade. Nesses casos os resultados são insatisfatórios, devido a dois fatores principais: falta de leituras acessíveis e/ou pouca familiaridade de estudantes e professores com o tema.

Embora a Geologia esteja sempre em busca de regularidades e princípios gerais (Sequeiros et al. 1996), é uma ciência "sempre obrigada a trabalhar com acontecimentos singulares, alguns dos quais são determinantes do que acontecerá depois”. A irreversibilidade contida em qualquer história - entre as quais se incluem as histórias geológicas - levanos a tentar compreender essa organização sem procurar reduzi-las às "regularidades subjacentes ou a um caos de acontecimentos arbitrários, mas compreender coerências e fatos: coerências que tanto podem resistir aos acontecimentos e condená-los à insignificância, como, ao contrário, ser destruídas e transformadas por alguns deles (...)" (Prigogine \& Stengers 1988, apud Sequeiros et al. 1996).

Quadro 2 - Algumas abordagens didáticas sobre datações

\section{Exemplos de experimentos e simulações - Datações}

1. Conceitos básicos de datação relativa ou absoluta

Conceitue:

- Atualismo

- Escala absoluta de tempo

- Estratigrafia

- Extinção em massa

- Fóssil-índice

- Geocronologia

- Meteorito

- Princípio da Superposição

- Relação de interseção

- Seqüência não-invertida

\section{Determinação de idade radiométrica}

Considere que sua equipe recebeu dois pedaços de cartolina, um de cor suave e outro de cor intensa. As partes devem ser justapostas e firmemente coladas uma à outra. Depois, divide-se a peça em duas metades, separando uma delas. A metade restante é novamente dividida, separa-se uma das novas metades e repete-se a divisão até formar uma espécie de quebra-cabeças como o da figura 14. Para organizar o que- bra-cabeças, coloque a peça quadrada maior com a cor suave para cima e todas as restantes com a cor intensa para cima.

- Será pedido que os alunos, a intervalos de tempo regulares, por exemplo de 1 minuto, virem o pedaço maior de cartolina de cor intensa, fazendo ficar para cima a cor suave. Repete-se o procedimento, sucessivamente, até que se considere oportuno interromper a atividade. Sabemos a taxa de inversão dos pedaços, que corresponde à meia-vida do elemento radioativo, é de 1 minuto, neste caso.

- Examinando-se o resultado do quebra-cabeças, pede-se que os estudantes calculem há quanto tempo o exercício foi iniciado.

Depois, reorganizando-se o quebra-cabeças, cada grupo de alunos deverá abrir as peças como quiser, segundo a mesma ordem das peças maiores para as menores. Ao trocar as peças dos grupos entre si, cada grupo poderá perguntar ao outro quanto "tempo" se passou desde a formação da rocha considerada, desde que se informe qual a taxa de desintegração radioativa utilizada. 
Quadro 3 - Algumas abordagens didáticas sobre História da Terra e Tempo Geológico

\section{Exemplos de experimentos e simulações - Tempo Geológico}

\section{Idade absoluta e a Escala do Tempo Geológico}

Examine a Escala do Tempo Geológico (Fig. 4).

- Calcule uma escala adequada para representar os dados da tabela, em uma seqüência ordenada no tempo, dispondo-se de uma fita longa, por exemplo dessas de máquina de calcular, com pelo menos 4,5 metros de comprimento.

- Construa a escala na fita de 4,5 m, adotando espaçamento linear (não-logarítmico). Qual deve ser a grandeza correta para cada período assinalado na tabela?

- Na mesma escala qual seria a posição e a dimensão dos seguintes eventos importantes da história geológica da parte brasileira do continente sul-americano?

a) Formação da bacia sedimentar do Pantanal: 2 milhões de anos atrás.

b) Formação das rochas cristalinas (ígneas e metamórficas) mais antigas da região da Serra dos Carajás: 2,8 a 3,4 bilhões de anos atrás.

c) Formação das rochas cristalinas (ígneas e metamórficas) mais jovens da região sudeste brasileira: 650 a 550 milhões de anos atrás.

d) Formação de petróleo na Bacia de Campos: desde 120 milhões de anos atrás.

e) Elevação das montanhas da Serra do Mar: 70 a 2 milhões de anos atrás.

f) Fundação da vila de Piratininga pelos jesuítas no Brasil: 1554.

- Como o homem se situa nesta escala?

- Qual é a relação entre o homem e o aparecimento dos seres vivos referidos na tabela?

\section{Idade relativa e sequiência de eventos}

Imagine que você integra uma equipe incumbida de construir a árvore genealógica de uma família numerosa. O trabalho não poderá utilizar depoimentos pessoais, pois muitos parentes morreram. Entretanto, um deles armazenou cuidadosamente um grande acervo de baús, com roupas, relíquias, jornais de época, fotografias, documentos e cartas pessoais.

O objetivo é estabelecer as relações de parentesco e a ordem provável dos membros da família, do mais velho para o mais novo. Ao final da pesquisa, vocês provavelmente terão uma cronologia absoluta de datas de nascimento e morte das pessoas, junto com outras informações que podem não estar bem amarradas na escala absoluta.

- Os dados trazidos pelos materiais guardados, ao se organizar as informações, podem ser considerados testemunhos do passado, do ponto de vista da cronologia?

- As roupas ajudam a reconhecer as épocas em que viveram as pessoas ilustradas nas fotografias? De que modo?

- Relações de parentesco definem uma cronologia absoluta ou relativa?

- Quais são os atributos indispensáveis para estabelecimento de uma cronologia absoluta?

- Compare suas respostas com as idéias de "fósseis" e "rochas como arquivos históricos".

- Que características devem ter um evento marcante para que tenha importância similar à de um fóssil-índice para a reconstrução dessa história?

\section{Eventos raros}

Discuta a seguinte proposição: "a história da Terra pode ser comparada à vida de um soldado: longos períodos de monotonia interrompidos por breves momentos de terror" (Ager 1973, apud Gretener 1984).

\section{Sucessão de eventos}

Discuta as idéias implícitas no seguinte verso:

"Reina a profundidade ali, onde a árvore cresceu. Oh! Terra, que mudanças tu tens visto!

Onde agora existe o sussurrar das ruas já existiu A suavidade do pleno oceano".

(Tennyson, apud Holmes 1923). 


\section{O dilema entre medir ou seqüenciar idades de rochas...}

A aplicação dos princípios da Estratigrafia, da Paleontologia e dos métodos de datação inicia-se com o estudo das unidades geológicas no campo. A partir dessa base de dados, pode-se definir corretamente qual (ou quais) evento(s) se pretende datar utilizando-se as técnicas da Geocronologia. Assim, é possível selecionar as amostras de rocha mais adequadas, ou seja, mais representativas do material a ser datado, o que requer controle rigoroso das amostras de rocha, bem como um cuidadoso estudo da idade geológica dos materiais. Evidências de idade relativa são, pois, essenciais para se determinar a idade geológica: é preciso estabelecer as relações entre uma determinada rocha e as outras ao seu redor.

Nas datações radiométricas analisamos os minerais componentes da rocha ou a rocha como um todo. Portanto, se a rocha teve história longa e complexa, este fator deve ser bem controlado em todas as suas variáveis.

\section{a. Complementaridade de métodos}

Para determinar a idade geológica, são essenciais as evidências de idade relativa dos materiais, ou seja, é preciso estabelecer relações cronológicas de uma rocha com as demais. Suponhamos um corpo de rocha metamórfica (Fig. 15), radiometricamente datado em $620 \mathrm{Ma}$, formado por duas partes: uma clara e outra mais escura, quase preta. Sabe-se que rochas metamórficas originam-se a partir de outras, preexistentes, e, portanto, o primeiro problema é saber qual das duas partes, que no exemplo é um gnaisse, formou-se primeiro e quais as etapas em que se originou a rocha metamórfica.

Na figura 15 nota-se que a rocha é cortada por falhas. Sabe-se ainda que, na metade direita da foto, o gnaisse é atravessado por pequena intrusão de diorito; as falhas atravessam apenas o gnaisse - não cortam o diorito. Os minerais componentes da rocha permitem obter datações, mas as falhas muitas vezes não oferecem material adequado. Admita-se que, nos mapas, ambos os corpos (o de gnaisse, metamórfico, e o de diorito) sejam recobertos por sedimentos de idade devoniana, datados pela Paleontologia. Pelo princípio das relações de intersecção, determinamos a idade relativa das falhas e do diorito: as falhas são mais antigas que o diorito e ambos formaram-se em algum momento durante o intervalo 620-416 Ma, ou seja, entre a idade das rochas metamórficas e o início do Devoniano (416$359 \mathrm{Ma}$ ). A datação radiométrica do diorito revelaria mais precisamente quando se formaram as falhas, mas apenas dentro de um intervalo de idades.

Rochas metamórficas são produtos de modificações no estado sólido, a partir de outras rochas preexistentes. Até mesmo sucessivos eventos de cristalização ao redor de cristais mais antigos podem

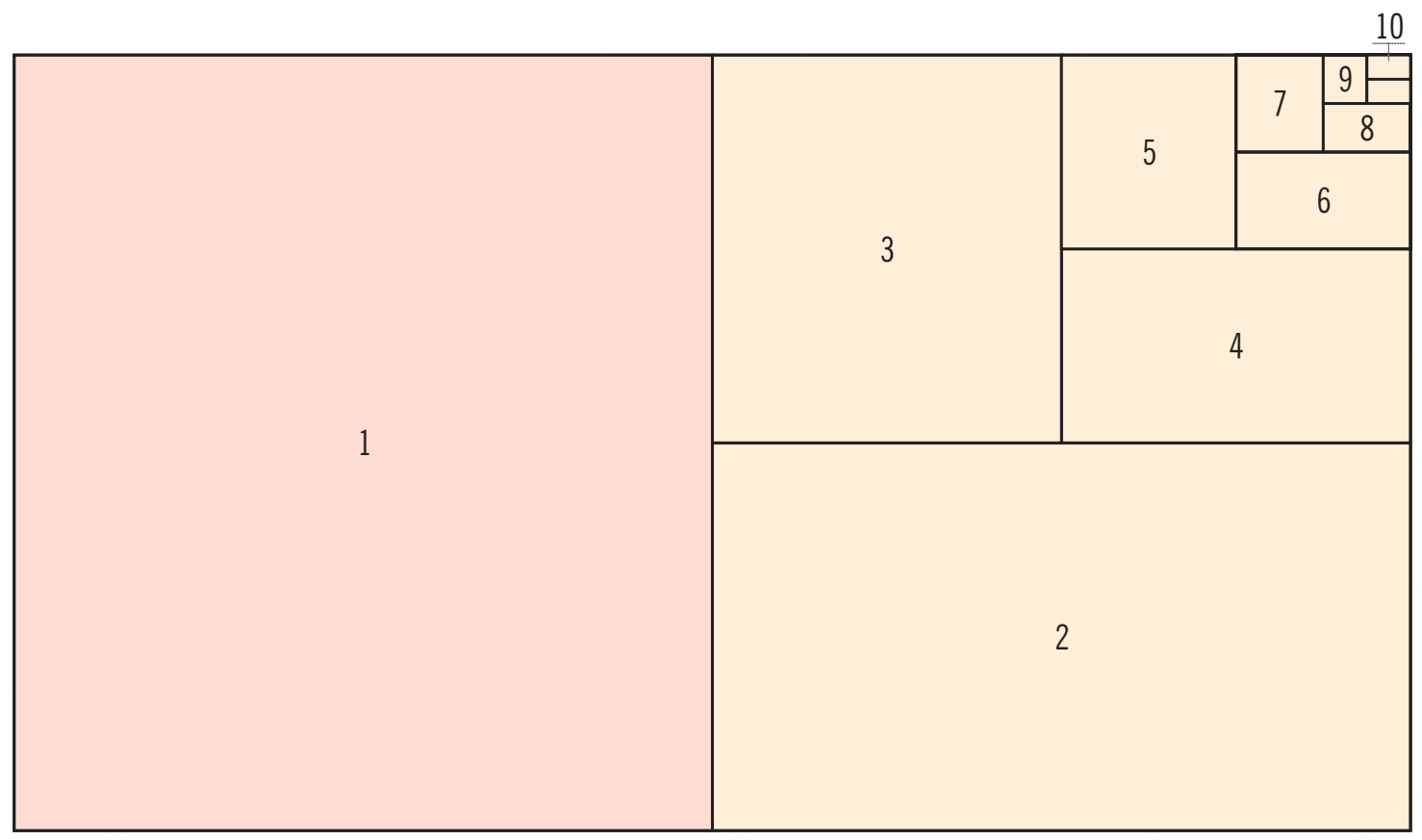

Figura 14 - Diagrama para simulação do mecanismo de determinação radiométrica de idades em rochas, conforme procedimento descrito no quadro 3 (baseado em Sequeiros et al. 1996) 
ser investigados, fornecendo dados cada vez mais completos sobre a evolução geológica da região. Portanto, se o conjunto rochoso teve história longa e complexa, pode-se realizar estudos microscópicos para se identificar diferentes gerações de minerais que, por sua vez, isoladamente, seriam passíveis de datação. No nosso exemplo, foi datado o episódio de metamorfismo mais jovem. Em outras palavras, precisaríamos, para conhecer a história geológica da região, coletar mais dados sobre os materiais que deram origem ao gnaisse e controlar quando se formaram as falhas.

Enfim, para conhecer a história natural do chão sob nossos pés, é fundamental saber as idades de formação e as sucessivas modificações que os diversos materiais terrestres sofreram. Para se ter controle preciso daquilo que se observa no laboratório e no campo, a pesquisa retorna sempre ao ambiente natural, onde ficam os vestígios dessa história, que está em permanente construção.

\section{Referências}

Ager, D.V. 1963. Paleoecology. An introduction to the study of how and where animals and plants lived in the past. New York: McGraw-Hill. 371p.

Albritton Jr., C.C. 1989. Catastrophic episodes in earth history. London: Chapman \& Hall, 221p.

Almeida, F.F.M. de; Carneiro, C.D.R. 1995. Geleiras no Brasil e os parques naturais de Salto e Itu. Ciência Hoje, 19(112):24-31. Agosto.

Almeida, F.F.M. de; Carneiro, C.D.R. 1998. Botucatu: o grande deserto brasileiro. Ciência Hoje, 24 (143):36-43. Outubro.

Almeida, F.F.M. de; Carneiro, C.D.R. 2004. Inundações marinhas fanerozóicas no Brasil e recursos minerais associados. In: Mantesso Neto, V.; Bartorelli, A.; Carneiro, C.D.R.; Brito-Neves, B. B. orgs. 2004. Geologia do Continente Sul-Americano: Evolução da obra de Fernando Flávio Marques de Almeida. São Paulo: Beca. p. 43-60. (Cap. 3).

Alvarez, L.W.; Alvarez, W.; Asaro, F.; Mitchel, H.V. 1980. Extraterrestrial cause for Cretaceous/ Tertiary extinction. Science, 208:1095-1109.

Arthur, M.A. 1993. When words collide: the endCretaceous global crisis. Earth and Mineral Sciences, 62(1):3-12

Attendorn, H.G.; Bowen, R.N.C. 1997. Radioactive and stable isotope Geology. London: Chapman \& Hall, 522p.

Bradshaw, M.J. 1973. A new geology. London: Hodder and Stoughton Educ., 280p.

Carneiro, C.D.R.; Almeida, F.F.M. de. 1989. Vulcões no Brasil. Ciência Hoje, 11(62):29-36.

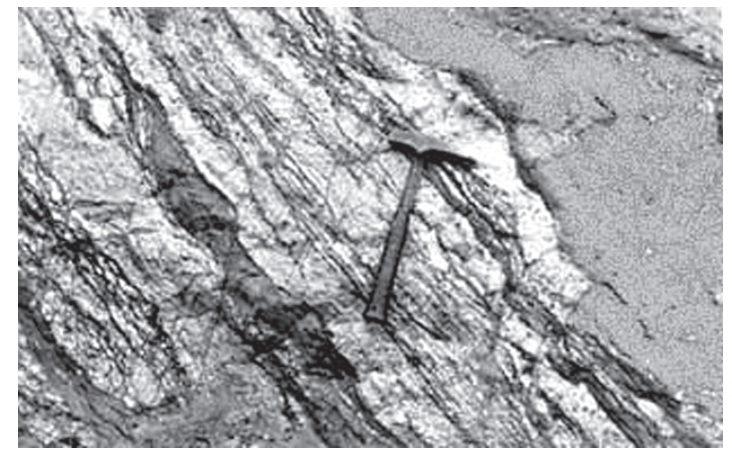

Figura 15 - Exposição de rocha metamórfica bandada, composta por bandas pouco regulares de material claro e escuro, de diferentes composições mineralógicas. Falhas discretas cortam o conjunto (descontinuidades inclinadas para a esquerda, na foto), mas não afetam o diorito, de cor cinza-médio

Carneiro, C.D.R.; Brito-Neves, B.B. de; Amaral, I.A. do; Bistrichi, C.A. 1994. O Atualismo como princípio metodológico em Tectônica. Bol. Geoc. Petrobrás, 8(2/4):275-293.

De Paolo, D.J.; Wasserburg, G.J. 1976. Inferences about magma sources and mantle structure from variations ${ }^{143} \mathrm{Nd} /{ }^{144} \mathrm{Nd}$. Geophys. Res. Letters, 3:743-746.

De Paolo, D.J. 1981. Neodimium isotopes in the Colorado Front Range and crust-mantle evolution in the Proterozoic. Nature, 291:193-196.

Dickin, A.P. 1995. Radiogenic isotope geology. Cambridge: Cambridge University Press. 490p.

Duarte, O.O. 1997. Dicionário enciclopédico InglêsPortuguês de Geofísica e Geologia. Ed. Prel. Rio de Janeiro: Petrobras. 304p.

Eicher, D.L.; McAlester, A.L. 1980. History of the Earth. Englewood Cliffs: Prentice-Hall. 413 p.

Eicher, D.L. 1969. Tempo geológico. São Paulo: Blücher/Edusp. (série Textos Básicos de Geociência).

Erwin, D.H 1996. The mother of mass extinctions. Scientfic American, p. 56-62. July.

Foster, R.; Skinner, B.J. 1977. Physical geology. 2 ed. New York: J. Wiley.

Gaessner, M.F. 1984. The down of animal life. Cambridge: Cambridge University Press.

Geyh, M.A.; Schleicher. 1992. Absolute age determination. Berlin: Springer-Verlag. 503p.

Gohau, G. 1991. A history of Geology. New Brunswick: Rutgers Univ. Press. 259p. (rev. and transl. from the French by A.V. Carozzi \& M. Carozzi).

Gould, S.J. 1965. Is Uniformitarianism Necessary? Am. J. Sci., 263:223-228.

Gould, S.J. 1967. Is Uniformitarianism Useful? In: Cloud, P. ed. 1970. Adventures in Earth History. San Francisco: Freeman. p. 51-53. 
Gould, S.J. 1984. Toward the vindication of punctuational change. In: Berggren, W.A. \& Van Couvering, J.A. eds. Catastrophes and Earth history. Princeton: Princeton Univ. Press. p. 9-34.

Gould, S.J. 1987. Seta do tempo. Ciclo do tempo. São Paulo: Cia. das Letras. 221p.

Gradstein, F.M.; Ogg, J.G.; Smith, A.G.; Bleeker W.; Lourens, L.J. 2004. A New Geologic Time Scale, with special reference to Precambrian and Neogene. Episodes, 27(3):83-100.

Gretener, P.E. 1984. Reflections on the "rare event" and related concepts in geology. In: Berggren, W.A. \& Van Couvering, J.A. eds. 1984. Catastrophes and Earth history. Princeton: Princeton Univ. Press. p. 77-89.

Guidon, N.; Pessis, A.-M. 1999. Datações em Arqueologia. In: SBPC. Tempo e Espaço (série Ciência Hoje na Escola), livro 7, p. 20-24.

Hellman, H. 1999. Grandes debates da ciência: dez das maiores contendas de todos os tempos. Trad. Marques, J.O.A., original de 1998. São Paulo: Unesp. 277p.

Holmes, A. 1923. A idade da Terra. Introdução às teorias geológicas. Trad. Correia, A.M. Lisboa: Ed. Inquérito. (Série F - Ciência IV).

Hooke, R.L. 2000. On the history of humans as geomorphic agents. Geology, 28(9):843-846.

Hsü, J.K. 1980. Terrestrial catastrophe caused by cometary impact at the end of Cretaceous. Nature, 265 : 201-203.

Lolson, E.C. 1982. Extintions of Permian and Triassic non-marine vertebrates. In: Silver, L.T. \& Schultz P.H. eds. Geological implications of impacts of large asteroids and comets on the Earth. Geol. Soc. Am. Spec. Paper, 190:501-511.

Mizusaki, A.M.P.; Carneiro, C.D.R.; Almeida, F.F.M. de. 2000. As idades das rochas. In: Carneiro, C.D.R. (Editor cient.). 2000. Geologia. São Paulo: Global/SBPC - Projeto Ciência Hoje na Escola. 80p. (Série Ciência Hoje na Escola, v. 10).

Nir, D. 1983. Man, a Geomorphological agent. Jerusalem, Israel: Keter Publ. House. 165p.

Pedrinaci, E.; Sequeiros, L. 1994. El concepto de tiempo geológico: orientaciones para su tratamiento en la Educación Secundária. Rev. de la Enseñanza de las Ciencias de la Tierra, 2(1):240-251.

Popp, J.H. 1987. Introdução ao estudo da estratigrafia e da interpretação de ambientes de sedimentação. Curitiba: Scientia et Labor. 323p.

Poupeau, G. 1980. Fission track dating. Ciência e Cultura, 33(3):325-352.

Press, F.; Siever, R. 1986. Earth. 4 ed. New York: Freeman.

Read, H.H.; Watson, J. 1968. Introduction to Geology. 2 ed. London: Macmillan. 693p. (v.1, Principles)
Rohn. R. 2000. Uso estratigráfico dos fósseis e tempo geológico. In: Carvalho, I.S. Paleontologia. Rio de Janeiro: Ed. Interciência. p. 47-59.

Sepkoski Jr., J.J. 1982. Mass extintions in the Phanerozoic oceans: a review In: Silver, L.T. \& Schultz, P.H., eds. Geological implications of impacts of large asteroids and comets on the Earth. Geol. Soc. Am. Spec. Paper, 190:283-289.

Sepkoski Jr., J.J. 1986. Phanerozoic overview of mass extinction, In: Raup, D.M. \& Jablonski, D. eds. Patterns and Processes in the History of Life. Berlin: Springer-Verlag. p. 277-295.

Sequeiros, L.; Pedrinaci, E.; Berjillos, P. 1996. Como enseñar y aprender los significados del tiempo geológico: algunos ejemplos. Rev. de la Enseñanza de las Ciencias de la Tierra, 4(2):113-119.

Svitl, K.A. 1998. Probing the Past. Discover, 19(1): 96-101.

Tarbuck, E.J.; Lutgens, F.K. 1996. Earth. An introduction to physical geology. New Jersey: Prentice-Hall. 605p.

Van Loon, A.J. 2001. Changing the face of the Earth. Earth-Science Reviews, 52:371-379.

Weiner, J. 1988. O Planeta Terra. São Paulo: Martins Fontes. 361p.

Zanda, B. 1996. Les meteorites. Le dossier. Geochronique, 60:12-19.

\section{a. Alguns sites relacionados na internet}

Uma pequena amostra, indicativa, de alternativas disponíveis na rede mundial de computadores:

http://geology.about.com/cs/basics_time/ http://geology.usgs.gov/index.shtml/ http://pubs.usgs.gov/gip/geotime/age.html http://pubs.usgs.gov/gip/geotime/index.html http://pubs.usgs.gov/gip/geotime/radiometric.html http://pasadena.wr.usgs.gov/office/ganderson/es10/ lectures/lecture14/lecture14.html

http:/volcano.und.nodak.edu/vwdocs/vwlessons/ plate_tectonics/

http://www.geology.sdsu.edu/how_volcanoes_work/ http://www3.uakron.edu/envstudies/historical/ hglect.html

http://www.dinosauria.com/dml/maps.htm - "Maps of Ancient Earth"

http://www.search4dinosaurs.com/pictures.html "Find Dinosaur Pictures"

http://www.geocities.com/historiadaterra/ http://earthsys.ag.ohio-state.edu/earth_today.html http://www.ig.utexas.edu/research/projects/plates/ plates.htm\# recons.

Submetido em março de 2002, atualizado em novembro de 2005. 